

\title{
Essential Roles of Intracellular Calcium Release Channels in Muscle, Brain, Metabolism, and Aging
}

\author{
Gaetano Santulli ${ }^{1,2, *}$ and Andrew R. Marks ${ }^{1,2,3}$
}

\author{
${ }^{I}$ The Wu Center for Molecular Cardiology, ${ }^{2}$ Department of Physiology and Cellular Biophysics, \\ College of Physicians and Surgeons, Columbia University Medical Center, ${ }^{3}$ Department of Medicine, \\ Columbia University, New York, NY
}

\begin{abstract}
Summary: Calcium $\left(\mathrm{Ca}^{2+}\right)$ release from intracellular stores controls numerous cellular processes, including cardiac and skeletal muscle contraction, synaptic transmission and metabolism. The ryanodine receptors (RyRs: RyR1, RyR2, RyR3) and inositol 1,4,5-trisphosphate receptors (IP3Rs: IP3R1, IP3R2, IP3R3) are the major $\mathrm{Ca}^{2+}$ release channels (CRCs) on the endo/sarcoplasmic reticulum (ER/SR). RyRs and IP3Rs comprise macromolecular signaling complexes that include modulatory proteins which regulate channel activity in response to extracellular signals resulting in intracellular $\mathrm{Ca}^{2+}$ release. Here we focus on the roles of CRCs in heart, skeletal muscle, brain, metabolism, and aging.
\end{abstract}

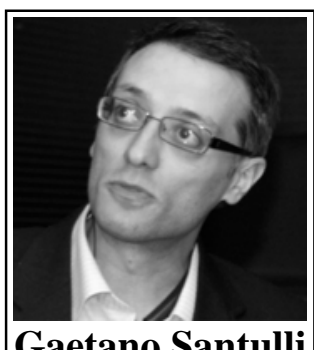

Keywords: Aging, arrhythmias, cognitive dysfunction, diabetes, excitation-contraction coupling, heart failure, IP3 receptors, metabolism, mitochondria, neurodegenerative disorders, RyR, skeletal muscle.

\section{INTRODUCTION}

Calcium $\left(\mathrm{Ca}^{2+}\right)$ is an essential signaling molecule in all cells. Indeed, $\mathrm{Ca}^{2+}$ is involved in numerous fundamental functions, including cell life and death [1-4]. Between these two events, $\mathrm{Ca}^{2+}$ finely regulates countless events as gene transcription, secretion, muscle contraction, and generation of fuels in various metabolic pathways, to name but a few [58]. Cytosolic $\mathrm{Ca}^{2+}$ signals are produced by rapidly increasing the concentration of free $\mathrm{Ca}^{2+}$ ions [9] by opening channels permeable to $\mathrm{Ca}^{2+}$ either in the surface cell membrane or in the membranes of intracellular organelles containing high $\mathrm{Ca}^{2+}$ concentrations, namely the endoplasmic and sarcoplasmic reticula (ER, SR). Amplification of external stimuli by triggering the release of intracellular $\mathrm{Ca}^{2+}$ stores is a common signaling mechanism in the cell. The ER/SR represents a heterogeneous compartment constituted by interconnected network of tubules $[10,11]$. Besides constituting the major $\mathrm{Ca}^{2+}$ reservoir within the cell, being thereby crucial in the fine regulation of intracellular $\mathrm{Ca}^{2+}$ concentration, the ER/SR is involved in a plethora of functional processes [12], including protein synthesis and protein transport, stress signaling, lipid synthesis, carbohydrate metabolism and detoxification reactions [5, 13-15].

The ER/SR of most cell types presents two types of intracellular $\mathrm{Ca}^{2+}$ release channels (CRC): the ryanodine receptors (RyRs) and the inositol 1,4,5-trisphosphate receptors (IP3Rs)

\footnotetext{
*Address correspondence to this author at The Wu Center for Molecular Cardiology, Department of Physiology and Cellular Biophysics, College of Physicians and Surgeons, Columbia University Medical Center, Department of Medicine, Columbia University, New York, NY; Tel:/Fax: 1-212-851-5348; E-mails: gsantulli001@gmail.com; gs2620@columbia.edu
}

[16]. There is $\sim 40 \%$ homology between the RyR and IP3R in the putative transmembrane regions, a sequence similarity sufficient to indicate that these two channels evolved from a common ancestral cation release channel in unicellular species.

The evaluation of the phylogeny of these two channels suggests that RyRs arose from ancestral IP3R-like channels by incorporating promiscuous 'RyR' and 'SPRY' domains (so named because these sequence repeats were identified in both Dictyostelium discoideum tyrosine kinase Spore lysis A, splA and the mammalian RyR) via horizontal gene transfer. Indeed, the structure of the mammalian RyR1 has recently been solved showing that it is a member of the six transmembrane ion channel family [17]. Putative RyRs and IP3Rs have been also identified in unicellular organisms including Capsaspora owczarzaki, Salpingoeca rosetta, and Monosiga brevicollis as well as in pathogenic unicellular parasites including Leishmania major, Leishmania infantum, Tryponosoma cruzi, and Tryponosoma brucei $[18,19]$. Though structurally related, RyRs and IP3Rs have distinct physiologic and pharmacologic profiles [20].

\section{RyRs}

RyR is a member of the same gene family as IP3R, but has evolved specialized functions relevant to excitationcontraction (E-C) coupling in striated muscles [21] and is developmentally regulated [2, 22].

RyR is a homotetramer comprised of four $565 \mathrm{kDa}$ monomers [23], of approximately 5000 amino acids each [17]. There are three subtypes of RyRs in mammalian tissues: RyR1 and RyR2 are required for skeletal muscle and cardiac E-C coupling, respectively [21, 24], and are also expressed in various non-muscle tissues [5, 25]; RyR3 was 
originally identified in the brain [26] but exhibits an ubiquitous expression, as it is widely expressed in other nonneuronal tissues [27].

RyR was named based on its purification using the high affinity plant alkaloid ryanodine [28], an agent known to profoundly alter $\mathrm{SR} \mathrm{Ca}^{2+}$ release events [29]. When bound to RyR at low concentrations ryanodine locks the channel in a half open state, thereby resulting in depletion of $\mathrm{Ca}^{2+}$ from the SR and subsequent interruption of E-C coupling. This explains the historical use of extracts from the Ryania plant family by natives of South and Central America as poison for arrowheads: indeed the release of SR $\mathrm{Ca}^{2+}$ via the locked open RyRs causes tetany, and at high concentrations ryanodine blocks the channel [28]. RyR is normally closed at low cytosolic $\left[\mathrm{Ca}^{2+}\right](\sim 100-200 \mathrm{nM})$; at submicromolar cytosolic $\left[\mathrm{Ca}^{2+}\right], \mathrm{Ca}^{2+}$ binds to high-affinity binding sites on RyR increasing its open probability $\left(\mathrm{P}_{\mathrm{o}}\right)$. Channel activity is maximal at cytosolic $\left[\mathrm{Ca}^{2+}\right] \sim 10 \mu \mathrm{M}$ while elevating cytosolic $\left[\mathrm{Ca}^{2+}\right]$ beyond this point leads to a reduction in $\mathrm{P}_{\mathrm{o}}[30,31]$.

We recently solved by single-particle cryo-electron microscopy the structure of RyR1 [17], demonstrating that it adopts a four-fold symmetric mushroom-like superstructure, with the large 'cap' (about $80 \%$ of the mass) located in the cytosol and the 'stalk' embedded in the ER/SR membrane, with six transmembrane helices (S1-S6) per protomer surrounding the central pore [17]. Each protomer is built around an extended scaffold of alpha-solenoid repeats which include an aminoterminal, a bridging, and a core solenoid. At the extreme outer corners of the tetramer there are three SPRY domains and two pairs of RyR repeats, RY12 and RY34, the latter containing a regulatory protein kinase A (PKA) phosphorylation site. The RyR1 pore domain most closely resembles that of the voltage-gated sodium channel (NavAB) and presents a single cytosolic constriction in the ion conduction pathway, at the S6 bundle crossing [17]. Glycine residues in the pore-lining helices may operate as "hinges" to facilitate the orientation of the cytoplasmatic extension of S6 in order to modulate the aperture of the channel. Notably, Gly ${ }^{4934}$ is conserved in all RyR isoforms and in IP3R.

\section{RyR Macromolecular Complex}

The large and complex structure of RyR contains function-modifying phosphorylation sites and protein-binding domains, providing an attractive target for disease intervention. The high-resolution structure of native RyR1 revealed the complete domain structure of the channel in unprecedented detail [17]. RyRs are macromolecular signaling complexes, in which multiple proteins bind to a domain of the channel modulating its function [21, 32].

The $\mathrm{Ca}^{2+}$ stabilizing proteins calstabin 1 (calcium channel

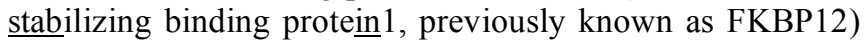
and calstabin2 (FKBP12.6) are peptidyl-propyl-cis-trans isomerases that associate via amphiphilic $\beta$-sheet structures with RyR1 and RyR2, respectively, such that one calstabin protein is bound to each RyR monomer [33-35], in order to regulate the channel gating through protein-protein interactions [36] and prevent pathological intracellular $\mathrm{Ca}^{2+}$ leak
$[37,38]$. Calstabin 1 and calstabin 2 differ at only 18 positions out of 108 residues.

We identified the calstabin-binding loop as part of the aminoterminal subdomain of the bridging solenoid [17]. Calstabin binding may rigidify the interface between such subdomain with SPRY1-2, thereby stabilizing the connection with the cytosolic regulatory domains and eventually altering the relative orientation of these domains [17]. Highly conserved leucine-isoleucine zipper motifs in RyR2 form binding sites for adaptor proteins that mediate binding of other proteins [32, 39], including kinases (e.g. PKA [40, 41], CaMKIIdelta [42]) and phosphatases (e.g. PP1 and PP2A). Specifically, the adaptor protein mAKAP mediates the binding of PKA and phosphodiesterase PDE43, whereas PP1 and PP2A are targeted to RyR2 via spinophilin and PR130, respectively [43, 44]. All of the above mentioned proteins regulate the phosphorylation-dephosphorylation of RyR2 in $\mathrm{Ser}^{2809}$ (Ser ${ }^{2808}$ in mouse) [45] in response to stress [45-48]. Other channels are also regulated by stress signals, including the voltage-gated $\mathrm{Ca}^{2+}$ channels [49]. RyR function is also affected by oxidation, nitrosylation, and other posttranslational modifications [5, 41, 45, 47, 50]. Many other modulatory proteins complex directly and indirectly with RyR, including sorcin [51], calmodulin [52], homer [53], histidine-rich $\mathrm{Ca}^{2+}$ binding protein [54], S100A1 [55], triadin [56], junctin [57], and calsequestrin [58].

\section{IP3Rs}

IP3R channels are homo or heterotetramers composed of four subunits (approximately 300,000 Da each). The structure of the IP3R monomer comprises a ligand-ligand pocket at the amino terminus, a central cytosolic regulatory domain, and a pore region containing six transmembrane helices forming the $\mathrm{Ca}^{2+}$ channel region located at the carboxy terminus $[57,59]$.

Three forms of IP3Rs (types 1, 2 and 3) have been characterized [60-63]. Virtually all cell types have at least one form of IP3R, and many express all three types. Additionally, the subcellular distribution of the three isoforms is celltype dependent [64]. IP3R1 has a broad tissue distribution but is especially abundant in the cerebellum, where it was initially purified and characterized [65]. It is also expressed in vascular smooth muscle cells, thyroid, uterus, and lymphocytes [20, 66, 67]. IP3R2 is expressed in cardiac muscle, as well as liver, kidney, and other epithelial tissues [68], while IP3R3 is expressed in endothelial cells, testis, endocrine and exocrine pancreas, spleen, gastrointestinal tract, and thymus [69].

IP3R function is regulated by at least two major cellular signaling pathways: the second messenger inositol 1,4,5trisphosphate (IP3) [70], produced primarily by phospholipase C (PLC) metabolism of phosphoinositol-4,5-bisphosphate (PIP2) in response to the stimulation of G-protein-coupled receptors (GPCRs) or receptor tyrosine kinases [1, 71, 72], and phosphorylation by non-receptor tyrosine kinases [73].

\section{IP3R Macromolecular Complex}

Numerous signaling molecules bind to IP3R regulating its function, including $\mathrm{Bcl}-2$, calmodulin [74], caldendrin 
[75], carbonic anhydrase-related protein (CARP) [76], ankyrin [77], homer [78], and IP3R-binding protein released by IP3 (IRBIT) [79]. Studies in murine T-cells demonstrated that the $\mathrm{BH} 4$ domain of $\mathrm{Bcl}-2$, which distinguishes antifrom pro-apoptotic members in the Bcl-2 family, is necessary and sufficient in binding to IP3Rs, inhibiting apoptosis [80]. The binding of Bcl-2 to IP3R promotes low-amplitude oscillatory $\mathrm{Ca}^{2+}$ signals and inhibits high-amplitude sustained elevations that are instead associated with cell death [81]. Intriguingly, a Bcl-2 binding site has been recently identified also in RyR2 [82]. CARP has been shown to bind IP3R1 causing conformational changes of the channel that reduce its affinity towards IP3 [76]. IRBIT suppresses the activation of IP3R by competing with IP3, acting as an endogenous pseudoligand whose inhibitory activity can be modulated by its phosphorylation status [83]. Moreover, the $\mathrm{IP}_{3} \mathrm{R}$ structure undergoes major conformational changes under influence of $\mathrm{Ca}^{2+}[84]$.

Various kinases, including CaMKII, Fyn, PKA PKG, and PKC, have been shown to phosphorylate IP3R [73, 85, 86]. We demonstrated that PKA and the phosphatases PP1 and PP2A are active components of the IP3R1 macromolecular complex [86]. A physical association between IP3R1 and calstabin1 had also been proposed [87] but subsequent studies have not been able to observe the formation of such interaction, despite detecting RyR1/calstabin 1 complexes in parallel experiments $[88,89]$.

\section{HEART}

$\mathrm{Ca}^{2+}$ is vital for the proper functioning of a healthy heart, as it is mechanistically involved in both myocardial contractile performance [90] and regulation of rhythmic beating [91]. Abnormalities in the regulation of $\mathrm{Ca}^{2+}$ homeostasis are associated with cardiovascular disorders including arrhythmias, myocardial hypertrophy, and heart failure. Cardiac contraction is a tightly regulated process beginning with depolarization of the sinoatrial node, situated at the junction between the right atrium and the superior vena cava. This generates a wave of depolarization that travels throughout the atria, converging onto the atrioventricular node, and from there spreading throughout the ventricles. $\mathrm{Ca}^{2+}$ finely orchestrates these processes, linking myocardial depolarization to myocardial contraction through E-C coupling [92]. Indeed, the rise in cytoplasmic $\left[\mathrm{Ca}^{2+}\right]$ is critical for activation of actin-myosin cross-bridging, shortening of the sarcomere, and muscle contraction.

\section{Cardiac Excitation-Contraction Coupling}

An Italian physician, Luigi Galvani, established in the $18^{\text {th }}$ century the relationship between electrical signaling and mechanical contraction conducting seminal experiments in frog legs, pioneering bioelectricity [93]. In 1883 Sidney Ringer was the first to discover that $\mathrm{Ca}^{2+}$ was a key component of cardiac contractility [6]. His observations were confirmed in 1913 by George Mines, who elegantly demonstrated that this specific ion was responsible for linking excitation and contraction [94]. Subsequent studies confirmed that cardiac contractility is directly proportional to systolic cytosolic $\left[\mathrm{Ca}^{2+}\right][95,96]$.

\section{RyR2 and Heart Failure}

Despite tremendous advances in the treatment of myocardial infarction, heart failure (HF), and cardiac arrhythmias [97], cardiovascular disease remains the leading cause of death worldwide, causing $\sim 600.000$ deaths per year in the US alone [98-100]. HF is associated with significant impairment in myocardial contractility, such that rates of both contraction and relaxation are slowed $[101,102]$.

RyR2 is responsible for $\mathrm{Ca}^{2+}$ release from the SR, where it is stored at high concentration (in the millimolar range), thereby raising the cytosolic $\left[\mathrm{Ca}^{2+}\right]$ about ten-fold (from $\sim 100 \mathrm{nM}$ to $\sim 1 \mu \mathrm{M}$ ) with each heartbeat in order to activate cardiac muscle contraction. Abnormal intracellular $\mathrm{Ca}^{2+}$ handling represents a major cause of decreased muscle contraction (systolic dysfunction) and defective relaxation (diastolic dysfunction) in patients with $\mathrm{HF}$, as confirmed by reports of reduced $\mathrm{Ca}^{2+}$ transient amplitude, increased $\mathrm{Ca}^{2+}$ transient duration, prolonged $\mathrm{Ca}^{2+}$ transient decay time, and decreased $\mathrm{SR} \mathrm{Ca}^{2+}$ load, leading to impaired contractility $[44,103]$. The mechanistic role of diastolic $\mathrm{Ca}^{2+}$ leak through dysfunctional RyR2 in the pathophysiology of HF has been experimentally established for the first time in 2000 [44].

RyR2 leak in HF is caused by stress-induced remodeling of the RyR2 macromolecular complex due to PKA hyperphosphorylation, oxidation, and nitrosylation of the channel, eventually resulting in an altered stoichiometry of the RyR2 complex, with displacement of calstabin2 [41], phosphatases [104], and PDE4D3 [43] from the channel. Depletion of PDE4D3 and phosphatases results in elevated levels of cyclic adenosine mono-phosphate (cAMP) [43] and a decreased rate of dephosphorylation, thereby promoting further PKA hyperphosphorylation. The term PKA hyperphosphorylation describes RyR2 in which 3-4 of the four RyR2 monomers are chronically PKA phosphorylated. Hyperphosphorylated/calstabin2 depleted channels are sensitized to cytosolic $\mathrm{Ca}^{2+}$, leading to inappropriate $\mathrm{Ca}^{2+}$ release during diastole, referred to as a diastolic SR $\mathrm{Ca}^{2+}$ leak. Most recently, we demonstrated that intracellular $\mathrm{Ca}^{2+}$ leak via RyR2 plays a key role in mitochondrial $\mathrm{Ca}^{2+}$ overload and dysfunction in HF [105].

As part of the classical 'fight-or-flight' response stress pathway [45], sympathetic nervous system activation causes catecholamine release and $\beta$-adrenergic receptor ( $\beta A R$ ) stimulation, increasing the gain of E-C coupling system and enhancing contractility [106]. Binding of catecholamines to $\beta A R s$ activates a $G$ protein-coupled intracellular signaling cascade [107-110], leading to the activation of adenylylcyclase with subsequent increased intracellular levels of cAMP, which in turn triggers PKA. RyR2 phosphorylation by PKA increases the $P_{0}$ of the channel by causing dissociation of the stabilizing protein calstabin2, resulting in increased sensitivity of RyR2 to $\mathrm{Ca}^{2+}$-dependent activation [44, 104].

Hyperactivation of sympathetic nervous system in HF is initially compensatory, but eventually accelerates the progression of the disease, posing severe toxicity on the chronically failing heart $[107,108,111]$. In this sense, the beneficial effects of $\beta A R$ blockers and other therapeutic approaches that mitigate or protect the heart against this sympathetic overdrive are well documented [108, 112, 113]. In- 
triguingly, the discovery of leaky RyR2 in HF [44] provides a compelling mechanism to explain the therapeutic efficacy of $\beta$ AR blockers in HF. Despite $\beta A R$ blockers represent a standard therapy in HF [108, 109], there is no accepted understanding of their exact mechanism of action in such a disease. In fact, multiple explanations have been suggested, including altered myocardial gene expression and increased $\beta A R$ density [109, 114].

We demonstrated that systemic administration of $\beta A R-$ blockers reduces PKA hyperphosphorylation of RyR2 and restores calstabin2 binding to RyR2 channels both in animal models of HF [115] and in cardiac samples from human heart transplant recipients [116]. We interpreted these findings as indicating that in failing hearts $\beta \mathrm{AR}$-blockers can indirectly fix the leak in RyR2 channels by inhibiting PKA hyperphosphorylation of the channel. This hypothesis was confirmed by proving that $\beta$ AR-blockers can improve cardiac function after MI in WT but not in RyR2-S2808D mice, in which $\mathrm{Ser}^{2808}$ of RyR2 is substituted with an aspartic acid residue, in order to mimic a constitutive PKA phosphorylation of the channel [41].

Alternative mechanisms underlying $\mathrm{SR} \mathrm{Ca}^{2+}$ leak in $\mathrm{HF}$ have been proposed, including phosphorylation of RyR2 by $\mathrm{Ca}^{2+} /$ Calmodulin kinase II (CaMKII) at $\operatorname{Ser}^{2815}\left(\mathrm{Ser}^{2814}\right.$ in mouse) [117]. However, we developed genetically altered mice that harboring RyR2 channels that cannot be phosphorylated by CaMKII (RyR2-S2814A), demonstrating in vivo that they were not protected against post-myocardial infarction HF progression [42]. Moreover, CaMKII phosphorylation of RyR2 is required for the rate-related increase in contractility [42]. Indeed, CaMKII is activated by $\mathrm{Ca}^{2+}$ itself and is exposed to more $\mathrm{Ca}^{2+}$ at higher heart rates, thereby resulting in increased CaMKII phosphorylation of RyR2, augmented SR Ca ${ }^{2+}$ release, and increased contractility (Bowditch phenomenon, frequency-dependent inotropy, or treppe [118]). Thus, CaMKII activation during HF is related to HR, which in turn increases the integral of cytosolic $\left[\mathrm{Ca}^{2+}\right][42]$. Additionally, CaMKII has been demonstrated to be also activated by oxidation [119-121], and the role of oxidative stress in cardiovascular disease is well established [105].

\section{RyR2 and Cardiac Arrhythmias}

Intracellular CRCs play a major role in arrhythmogenesis [43, 48, 122, 123]. Indeed, increased RyR2 activity causes atrial and ventricular arrhythmias, particularly associated with increased catecholaminergic stimulation [123-126]. Altered $\mathrm{Ca}^{2+}$ handling, as seen in $\mathrm{HF}$, contributes to triggered activity arising from early after-depolarization (EAD) or delayed afterdepolarization (DAD). EAD occurs in the setting of increasingly labile repolarization observed in HF, during phase 2 and phase 3 of the action potential. DAD occurs during phase 4 and results from elevated intracellular $\mathrm{Ca}^{2+}$ load and spontaneous $\mathrm{SR} \mathrm{Ca}^{2+}$ release, which leads to activation of transient inward current.

Besides the acknowledged role in providing a substrate for arrhythmias in patients with HF or cardiac hypertrophy $[43,127]$, RyR2 has also been linked to at least two forms of sudden cardiac death (SCD): catecholaminergic polymorphic ventricular tachycardia (CPVT) [5, 128] and arrhythmogenic right ventricular dysplasia type 2 (ARVD2) [129]. Moreover, exon 3 deletion of RyR2 has been associated with left ventricular noncompaction and CPVT [130].

CPVT is a rare inherited form of exercise-induced SCD that occurs in typically young individuals with structural normal hearts [5]. Several mutations in RyR2 have been linked to CPVT [128]. RyR2s with most of CPVT mutations exhibit reduced affinity for calstabin2, which results in leaky channels during exercise [131]. Calstabin2 deficient and haploinsufficient mice have CPVT and their RyR2 channels display slightly increased open probability at baseline that increases substantially following exercise [131].

ARVD is another inherited cardiac disorder characterized by substitution of the right ventricular myocardium with fibrofatty tissue, which appears to be a result of progressive death of cardiomyocytes resulting from a combination of inflammation and apoptosis [132, 133]. Twelve different types of ARVD have been identified hitherto, and type 2 is caused by mutations in $R y R 2$ [134]. Clinical presentation of ARVD is characterized by arrhythmias of right ventricular origin, ranging from premature beats to ventricular fibrillation, often leading to SDC [135]. Similar to CPVT, ARVD patients also exhibit exercise- and adrenergic-induced fatal arrhythmias. Available therapy for both CPVT and ARVD remain limited, and implantable cardioverter/defibrillator remains the best choice $[133,136]$. We have shown that pharmacological stabilization of RyR2 prevents intracellular $\mathrm{Ca}^{2+}$ leak and arrhythmias [137], providing a promising potential therapeutic option for these disorders.

Most recently, we and others have also demonstrated that leaky RyR2s are key players in the pathophysiology of atrial fibrillation (AF) $[123,124,138]$. We proved that atrial RyR2s from patients with chronic AF were oxidized, phosphorylated and depleted of calstabin2 [123]. Likewise, mice with intracellular $\mathrm{Ca}^{2+}$ leak exhibited increased atrial RyR2 oxidation, mitochondrial dysfunction, ROS production and AF susceptibility. Interestingly, AF could be prevented by inhibition of mitochondrial ROS generation and by pharmacological treatment of RyR2 leak [123], indicating that mitochondrial oxidative stress and alterations in RyR2 may form a vicious cycle in the development of AF.

\section{IP3Rs and Cardiac Disease}

The role of IP3Rs in the heart remains quite controversial $[105,139]$. Within cardiac myocytes, IP3R mRNA levels are 50-fold lower than that of the cardiac RyR mRNA [140]. The relative amount of IP3Rs is too low and the kinetics of $\mathrm{Ca}^{2+}$ release from IP3Rs is too slow compared with RyRs to contribute to the $\mathrm{Ca}^{2+}$ transient during E-C coupling. Besides, $\mathrm{Ca}^{2+}$ flux via RyR has been shown to be markedly larger than the flux through IP3R [141, 142].

The study of IP3-induced $\mathrm{Ca}^{2+}$ release in cardiomyocytes has been difficult because $\mathrm{Ca}^{2+}$ release from RyR2, required for E-C coupling, dominates in the heart [105]. Indeed, direct studies of $\mathrm{Ca}^{2+}$ release in response to IP3 in cardiac preparations have revealed $\mathrm{Ca}^{2+}$ responses that are of much lower magnitude than those seen with the RyR system [143]. Likewise, direct generation of IP3 in intact non-beating neonatal cardiomyocytes does not alter cytosolic free $\mathrm{Ca}^{2+}[144]$. 
$\mathrm{IP}_{3} \mathrm{Rs}$ are more abundant in atrial than in ventricular cardiomyocytes and even more abundant in conduction tissue cells $[145,146]$. Atrial and ventricular tissue express a similar proportion of IP3R1 and IP3R2 [145]; however, studies in isolated cardiomyocytes revealed that IP3R2 is clearly the predominant isoform in contractile myocardial cells and in sinoatrial node [147], whereas IP3R1 is the predominant isoform in other cell types, including endothelial cells and Purkinje fibers [145, 146]. In adult rabbit ventricular myocytes, $\mathrm{IP}_{3} \mathrm{Rs}$ were implicated in the regulation of gene expression, based on the finding that the endothelin 1-induced mobilization of $\mathrm{Ca}^{2+}$ from the nuclear envelope was blocked by 2 aminoethoxydiphenyl borate (2-APB) [148], which is though considered a reliable blocker of store-operated $\mathrm{Ca}^{2+}$ entry but an inconsistent inhibitor of IP3-induced $\mathrm{Ca}^{2+}$ release [149].

In summary, most studies are in agreement that activation of IP3Rs does not significantly contribute to cardiac E-C coupling. A functional role for these channels has been also proposed in the pathophysiology of cardiac arrhythmias as well as myocardial hypertrophy [150]. Indeed, a significant upregulation of IP3Rs mirrored by enhanced channel activity [151] has been observed in patients with chronic atrial fibrillation [152], which remains the most common sustained arrhythmias, affecting 2.3 million adults in the US [98, 153, 154]. A reduction of sustained arrhythmias after application of 2-APB has also been reported [155]. Moreover, increased IP3 generation in the heart has been associated with the induction of ventricular arrhythmias [156]. A marked increase in IP3 levels in the heart occurs during early post-ischemic reperfusion following activation of $\alpha_{1} \mathrm{AR}$ or thrombin receptor and correlates temporally with the development of ventricular tachycardia and fibrillation [156]. Of interest, inhibition of PLC-induced IP3 generation prevents reperfusion-related arrhythmias [157].

IP3Rs have been indirectly implicated in the development of left ventricular hypertrophy via upstream signaling pathways coupled to IP3, including $\alpha_{1} \mathrm{AR}$, angiotensin II, and endothelin-1. However, several studies have demonstrated a main role for diacylglycerol (the other product resulting from PLC hydrolysis) and subsequent PKC activation, more than a direct IP3R activation, in the induction of cardiac hypertrophy [158-160].

\section{SKELETAL MUSCLE}

Depolarization of skeletal myocytes involves a proteinprotein interaction [161] across the junctional cleft between the dihydropyridine receptor $\left(\mathrm{Ca}_{\mathrm{v}} 1.1\right)$ on specialized invaginations of the sarcolemma (transverse tubules) and RyR1 on the SR membrane (terminal cisternae) [162]. Ergo, $\mathrm{Ca}_{\mathrm{v}} 1.1$ acts as a marionettist on RyR1, eventually leading to $\mathrm{Ca}^{2+}$ release from the $\mathrm{SR}$.

Remarkably, RyRs were initially observed in skeletal muscle, visualized in electron micrographs as large electrondense masses located along the face of the SR terminal cisternae, which is closely apposed to transverse tubule membranes to form a structure named triad junction [163]. Therefore, the RyRs were initially termed triad junctional foot proteins [164, 165]. Noda and colleagues provided the in vivo evidence for a functional role of RyR1 in E-C coupling, engineering a mouse lacking exon 2 of RyRl and demonstrating that such a model exhibits severe skeletal muscle abnormalities and dies perinatally due to respiratory failure [166]. Subsequent ultrastructural studies of hindlimb and diaphragm muscles demonstrated the absence of RyR1Cav1.1 complexes [167], which are essential for a proper EC coupling in the skeletal muscle [168].

RyR1 dysfunction has been described in both inherited and acquired muscle disorders [169, 170]. Malignant hyperthermia $(\mathrm{MH})$ and central core disease $(\mathrm{CCD})$ represent the best examples of RyR1 channelopathies in the skeletal muscle [171].

\section{Role of RyR1 in Malignant Hyperthermia and Central Core Disease}

$\mathrm{MH}$ is a pharmacogenetic disorder, inherited in an autosomal dominant fashion and continues to be of major concern for anesthetic-induced deaths in otherwise healthy individuals [172]. $\mathrm{MH}$ episodes are typically rapid and severe, reaching core body temperatures of $43^{\circ} \mathrm{C}$, leading to organ failure and death if not rapidly treated. The exact prevalence of MH susceptibility is difficult to determine since the syndrome only becomes apparent after exposure to triggering agents including volatile anesthetic agents such as halothane, isoflurane, sevoflurane, desflurane, enflurane and the neuromuscular blocking agent succinylcholine [173]. Susceptibility can be determined in vitro by measuring the contractile response to caffeine or halothane in biopsied muscle fibers. A related syndrome referred to as porcine stress syndrome is found in certain lines of domestic swine where stressed pigs undergo stress-induced hyperthermia [174].

These disorders are thought to develop following extreme skeletal muscle contraction that results from excess $\mathrm{Ca}^{2+}$ in the myoplasm following anesthesia in humans or during stress in pigs; this $\mathrm{Ca}^{2+}$ overload causes sustained contractions, which accounts for the rapid onset of muscle rigidity, leading to an augmented metabolic demand on myocytes, which depletes ATP levels. Myocytes respond by increasing ATP production via oxidative phosphorylation and glycolysis, and such a prolonged hypermetabolic state generates heat. Alterations in ${ }^{3} \mathrm{H}$-ryanodine binding properties in porcine $\mathrm{MH}$ samples provided evidence linking RyR1 dysfunction to the disease [175], which was later confirmed by biophysical experiments [176].

CCD is a dominantly inherited congenital myopathy, first described in 1956 [177]. The name derives from the typical appearance of the biopsy on light microscopy, where the muscle cells have metabolically inactive tissue in the center of type I myofibers, appearing as cores that are devoid of mitochondria and specific oxidative enzyme stains. Common symptoms include hypotonia, delayed motor milestones, and skeletal abnormalities including congenital hip dislocation and scoliosis.

There is no clear division between $\mathrm{MH}$ and CCD and some $R y R l$ mutations have been linked to a combined $\mathrm{MH}$ and CCD phenotype [178]. Notably, most MH mutations in $R y R 1$ gene lead to a gain-of-function effect, with increased sensitivity to channel agonists, causing a leak in RyR1 channels, whereas most CCD-related mutations have been associated with channels displaying reduced conductance [179]. 
Importantly, the mutated codons giving rise to $\mathrm{MH}$ and CCD tend to cluster in three specific regions of the $R y R I$ gene, that correspond to the following domains in the aminoacidic sequence: regions 1 (C35-R614) and 2 (D2129$\mathrm{R} 2458$ ) reside in the myoplasmic foot domain of the protein, whereas region 3 (I3916-G4942) is located in the transmembrane/luminal region of the highly conserved carboxyterminal domain, important for allowing $\mathrm{Ca}^{2+}$ flux through the channel [17].

Mutations in RyRl are also associated with other rare CCD-related congenital myopathies including centronuclear myopathy, multi-minicore disease, Samaritan myopathy, congenital fiber-type disproportion, and nemaline myopathy [180-182].

\section{Role of RyRs1 in Muscular Dystrophy}

We established that intracellular $\mathrm{Ca}^{2+}$ leak via RyR1 represents an essential feature of different forms of muscular dystrophy (MD), including Duchenne MD [183] and limbgirdle (or Erb's) MD [169]. Specifically, RyR1 from a Duchenne MD murine model ( $m d x$ mouse) was excessively cysteine nitrosylated and depleted of calstabin1, leading to increased spontaneous RyR1 openings and overall reduced specific muscle force [183]. Similar findings were obtained when evaluating RyR1 in $\beta$-sarcoglycan-deficient mice, an established model of limb-girdle DM [169].

Thus, we demonstrated common mechanisms of maladaptation of RyR1, including post-translational modifications of the channel and dissociation of the stabilizing subunit calstabin1, in two major disorders that weaken the muscular system hampering locomotion and that remain virtually without effective pharmacological treatment. We proved in both cases that stabilizing the RyR1-calstabin1 association ameliorated muscle function [169, 183], thereby providing an innovative therapeutic target and potential options for the treatment of DM.

In conditions of strenuous muscular stress or in a disease such as HF, both of which characterized by chronic activation of the sympathetic nervous system and increased production of reactive oxygen and nitrogen species [108, 184, 185], skeletal muscle function is impaired, possibly due to altered E-C coupling. Indeed, the amount of $\mathrm{Ca}^{2+}$ released from the SR during each contraction of the muscle is reduced, $\mathrm{Ca}^{2+}$ reuptake is slowed, and aberrant $\mathrm{Ca}^{2+}$ release events can occur [40, 186].

We have shown in both an animal model as well as in exercising humans that chronic $\beta A R$ stimulation and depletion of calstabin 1 from RyR1 plays a mechanistic role in the contractile failure and muscle fatigue, defined as decline in ability of a muscle to generate force, observed during sustained exercise [187]. Consistent with these observations, we have demonstrated that the remodeling of RyR1 plays a pivotal role also in sarcopenia and muscle aging [47] and we were able to prevent RyR1 dysfunction and ameliorate skeletal muscle function in aging by genetically enhancing mitochondrial antioxidant activity [188], as extensively discussed in the dedicated section of this overview.

Since skeletal muscle dysfunction, as seen in HF or muscular disorders, remains practically without effective treat- ment, drugs that restore $\mathrm{RyR} \mathrm{Ca}^{2+}$ release function, represent promising candidates. In this sense, these drugs could be ideal in conditions with co-morbidity between cardiac and skeletal muscles. Indeed, as muscular RyR1 undergoes posttranslational modifications in $\mathrm{HF}[40,186]$, remodeling of the cardiac RyR2 has been also reported in mouse models of Duchenne MD, triggering ventricular arrhythmias [50].

\section{IP3Rs and Muscle Pathophysiology}

In contrast to the acknowledged prominent role of RyR1, there is no strong experimental evidence for a significant functional action of IP3R-mediated $\mathrm{Ca}^{2+}$ release in adult muscle fibers. Immunodetectable IP3Rs and specific $\left[{ }^{3} \mathrm{H}\right] \mathrm{IP} 3$-binding sites were reported to be preferentially expressed in slow oxidative (type I) and fast oxidative glycolytic (type IIA) fibers [189]. The presence of $\mathrm{IP}_{3} \mathrm{Rs}$ has been later confirmed in both rabbit and mouse skeletal muscle [190]. Most recently, the expression of the three isoforms has been investigated in adult murine skeletal muscle, revealing that IP3R1 is absent in slow-type muscle fibers and is expressed preferentially in fast, mixed metabolism (type IIX) fibers whereas IP3R2 and IP3R3 are ubiquitously expressed in all muscle fiber types [191].

Although IP3Rs have been shown to be present and functional in cultured muscle cells [192, 193], no significant change in $\mathrm{Ca}^{2+}$ signal has been detected in adult muscle fibers after IP3 microinjection or photolysis of membranepermeant IP3 [194]. Available data seem to converge towards a potential role of IP3Rs in neuromuscular junctions and in satellite cells [195].

\section{CENTRAL NERVOUS SYSTEM}

$\mathrm{Ca}^{2+}$ signaling regulates numerous neurological processes including synaptic transmission, secretion, excitability, learning, and memory. Emerging evidence suggests that several types of neurological disorders may share a common underlying mechanism, i.e. altered $\mathrm{Ca}^{2+}$ release from the ER [196-199]. The involvement of IP3Rs and RyRs in neurodegenerative disease relies at least in part on abnormal $\mathrm{Ca}^{2+}$ signaling that ultimately leads to excitotoxicity in specific areas of the central nervous system [200].

\section{Intracellular CRCs and Amyotrophic Lateral Sclerosis}

Amyotrophic lateral sclerosis (ALS), also known as Lou Gehrig's disease, is a rapidly progressing disease characterized by upper and lower motor neuron degeneration, eventually resulting in muscle atrophy and weakness throughout the body [201-203]. The current knowledge of its causes is very limited and it seems to derive from multiple and complex environmental factors and genetic predisposition [204, 205].

The most studied gene associated with ALS susceptibility is the copper-zinc superoxide dismutase [206, 207]. Several investigators have proposed an autoimmune origin for ALS [208, 209]. Supporting this view, Pagani and colleagues demonstrated that IgG isolated from $~ 50 \%$ of ALS patients can increase $\mathrm{Ca}^{2+}$ levels in motor nerve terminals in murine tissue cultures, enhancing spontaneous neurotransmitter release at neuromuscular junctions [210]. Of interest, both RyR and IP3R were necessary to maintain the IgG-dependent en- 
IP3R were necessary to maintain the IgG-dependent enhancement of neurotransmitter release [210].

Most recently, a genome-wide association study unveiled $I P 3 R 2$ gene as a potential player in sporadic ALS, identifying a specific mutation (rs2306677) in intron 42 of IP3R2 gene [211]. IP3R2 is a very plausible susceptibility gene for ALS since it is involved in glutamate-mediated neurotransmission, is one of the main regulators of intracellular $\mathrm{Ca}^{2+}$ concentrations, and is an important player in apoptosis [211].

The role of RyRs in ALS pathophysiology has been less studied. Intriguingly, an imbalance between RyR and calstabin in spinal cords of neurological controls and patients with motor neuron disease has been reported in a Japanese study, revealing a significantly decreased expression of calstabin in neurons from patients with ALS [212]. Moreover, dantrolene sodium, a myorelaxant currently used to treat malignant hyperthermia, neuroleptic malignant syndrome, spasticity and Ecstasy (3,4-methylenedioxy-metamphetamine, MDMA) intoxication, had been proposed as potential therapy for ALS [213]. Of note, even though dantrolene is generally labeled as 'RyR inhibitor', a precise mechanism of action has not been identified and several investigators have demonstrated that the RyR2 isoform is not a target of such a drug [214, 215]. Recently, Laver and colleagues reported that calmodulin is essential for dantrolene action [216]: its absence in single RyR assays might therefore explain why this drug does not inhibit RyR in lipid bilayer preparations.

\section{Intracellular CRCs and Alzheimer's Disease}

Alzheimer's disease (AD) is the most common type of dementia, characterized clinically by progressive deterioration of cognitive functions including memory, reasoning, and language. $\mathrm{Ca}^{2+}$ certainly plays a pivotal role in the pathogenesis of the disease. Indeed, altered $\mathrm{Ca}^{2+}$ signaling has been detected in brain cells from both AD patients and animal models of $\mathrm{AD}$, even before the appearance of amyloid $\mathrm{A} \beta$-plaques or tangles, considered pathological hallmark features of $\mathrm{AD}[217,218]$. Whether $\mathrm{A} \beta$-plaques are a cause or a consequence of $\mathrm{AD}$ remains controversial.

According to Demuro and Parker cytotoxicity of $A \beta$ amyloid oligomers involves $\mathrm{Ca}^{2+}$ release from the ER via activation of IP3Rs, as demonstrated in vitro in Xenopous oocytes [219]. Supporting this view, studies in fibroblasts isolated from patients with familial $\mathrm{AD}$ revealed that presenilins activate IP3Rs potentiating $\mathrm{Ca}^{2+}$ release from the ER [220]. These results have been confirmed in other cell types. Abnormal $\mathrm{Ca}^{2+}$ homeostasis in $\mathrm{AD}$ is further amplified by the increased $\mathrm{A} \beta$-amyloid production caused by IP3R activation [221], in a vicious cycle that ultimately leads to cell death.

Most recently, Foskett demonstrated that an exaggerated $\mathrm{Ca}^{2+}$ signaling mediated by IP3R1 contributes to AD pathogenesis [222]. On the other hand, several reports have shown alterations of expression and function of RyRs in different murine models of the disease, in human AD-affected brains, and in cells expressing familial AD-linked mutations on the $\beta$-amyloid precursor protein and presenilins [223-225]. Moreover, altered RyR2 expression has been reported in a study of the whole-genome expression profile of sporadic and monogenic early-onset AD [226]. Available data suggest that alterations in RyR-mediated $\mathrm{Ca}^{2+}$ handling are associated to $\mathrm{AD}$ etiopathogenesis through means of various mechanisms, including the regulation of $\mathrm{A} \beta$-amyloid production, synaptic function, memory and learning abilities, and neuronal death [227].

\section{Intracellular CRCs and Huntington's Disease}

Huntington's disease (HD) is a dominantly inherited genetic disorder characterized by dementia, slowly progressing movement disorders and psychiatric symptoms [228]. It is caused by an exaggerated polyglutamine expansion in the aminoterminus of the huntingtin protein. Mutant huntingtin impairs both protein folding and protein degradation. Interestingly, mutant huntingtin has been reported to disrupt $\mathrm{Ca}^{2+}$ signaling by forming a complex with the NMDA receptor and synapse-associated protein 90 (SAP-90) [229]. Additionally, huntingtin can bind and activate IP3R1 and impair mitochondrial function [230]. Consistent with these findings, the exogenous expression of the human mutant huntingtin in Drosophila melanogaster led to retinal degeneration, which was prevented by knocking-down IP3R1 [231].

\section{Intracellular CRCs and Post-Traumatic Stress Disorder}

Post-traumatic stress disorder (PTSD) presents with a diverse set of symptoms involving a mixture of psychological, social, and biological processes [232]. Neurobiological research did not clarify a clear mechanism underlying the disease, but overall, there is mounting evidence that symptomatology following experiences of traumatic stress may derive from effects on brain function and structure [232]. Current therapy for PTSD remains largely supportive, and not mechanism-based.

Using chronic restraint to induce stress in mice we recently demonstrated that hippocampal RyR2s of stressed mice were phosphorylated by PKA, oxidized and nitrosylated, inducing intracellular $\mathrm{Ca}^{2+}$ leak [46]. The mice also exhibited impaired cognitive performance in various behavioural tests, including the Morris water maze, which are known to depend on hippocampal function. Pharmacologic or genetic inhibition of the leak prevented the cognitive dysfunction [46]. Since stress-induced cognitive impairment shares many features with PTSD [233], the pathway that we elucidated could be a potential therapeutic target. The link between PTSD and ER $\mathrm{Ca}^{2+}$ has been also confirmed in the rat, validating a functional role for ER stress and apoptosis in the pathophysiology of the disease [234].

\section{Intracellular CRCs and Spinocerebellar Ataxias}

Spinocerebellar ataxias (SCA) are a group of genetic movement disorders characterized by progressive ataxia and cerebellar atrophy [235]. Since cerebellar Purkinje cells express high levels of IP3R1, this channel has been proposed as a key player in cerebellar long-term depression generation, which protects neuronal Purkinje cells against high glutamate stimulation [236].

Several types of SCA are caused by mutations that generate poliglutamine proteins, such as ATXN2 [237] and ATXN3 [238], which have been shown to bind IP3R1, potentiating ER $\mathrm{Ca}^{2+}$ release. Moreover, deletions of different 
regions of $I P 3 R I$ gene have been linked to other types of SCA, not associated with polyglutamine repeats [239, 240]. A profound derangement in IP3R1-dependent $\mathrm{Ca}^{2+}$ signaling has been also reported in the opisthotonos mouse, which is ataxic and convulsive [241].

\section{METABOLISM}

Mounting evidence indicates that changes in intracellular $\left[\mathrm{Ca}^{2+}\right]$ play a pivotal role in glucose homeostasis, modulating both insulin secretion from the pancreatic islets of Langerhans and insulin resistance in peripheral responses of liver, muscle and adipocytes [5, 242-245].

Several studies have demonstrated that altered cellular $\mathrm{Ca}^{2+}$ homeostasis is a key contributor to impaired beta cell function and survival in type 2 diabetes mellitus (T2DM) $[246,247]$. However, according to the classical view of the glucose sensing machinery, insulin secretion largely depends on the depolarization of the plasma membrane and the subsequent voltage-activated $\mathrm{Ca}^{2+}$ influx from the extracellular space $[248,249]$.

Most recently, we established both in humans and animal models [5] the mechanistic role of $\mathrm{Ca}^{2+}$ mobilization from the ER via RyR2 in insulin secretion, a topic that had remained controversial for decades. In fact, while the expression of IP3R1 [250, 251] and RyR2 [252-254] had been reported in pancreatic beta cells, their functional role had not been fully dissected heretofore.

\section{Intracellular CRCs and Glucose Homeostasis}

A seminal study revealed that mice with double knockout of IP3R2 and IP3R3 are lean and hypoglycemic despite a normal caloric intake, most likely as a result of difficulty in nutrient digestion, and exhibit severe impairment in $\mathrm{Ca}^{2+}$ signaling and secretion in acinar cells of the exocrine tissues [255]. Moreover, variations within IP3R3 had been identified as a risk factor for type 1 diabetes mellitus (T1DM) in humans [256]. However, a subsequent study based on a familybased approach, which is not subject to population stratification, did not confirm an obvious role of genetic variation of the IP3R3 gene in T1DM risk [257].

A demonstration of a connection between glucosestimulated insulin secretion and $\mathrm{Ca}^{2+}$ signaling through $\mathrm{IP}_{3-}$ sensitive $\mathrm{Ca}^{2+}$ stores comes from mice heterozygous for the anx7 gene, which encodes for $\mathrm{Ca}^{2+}$-activated GTPase supporting $\mathrm{Ca}^{2+}$ channel activities [258]. These mice exhibit defects in IP3R expression, and $\mathrm{Ca}^{2+}$ signaling in panreatic islets, and impaired insulin secretion [258]. Moreover, PKAmediated promotion of $\mathrm{Ca}^{2+}$-induced $\mathrm{Ca}^{2+}$ release via IP3Rs has been implicated as part of the mechanism by which cAMP amplifies insulin secretion [259].

The potential involvement of RyR2 in insulin release has been suggested by in vitro experimental data showing an enhanced $\mathrm{Ca}^{2+}$ response in beta cells following caffeine treatment [260]. RyRs had been proposed to be located on insulin granules [261] but Polonsky and colleagues subsequently demonstrated that RyRs do not co-localize with secretory granules [252]. Additionally, the finding that genetic deletion of the RyR2 subunit calstabin2 induces impaired glucose-induced insulin secretion in mice suggests a functional role for RyR2 in glucose homeostasis [262].

We exploited rare RyR2 mutations identified in patients with CPVT to assess RyR2 function in beta cell dynamics. We discovered that CPVT patients with mutant leaky RyR2 present with glucose intolerance [5]. In mice, transgenic expression of CPVT-associated mutated RyR2 resulted in impaired glucose homeostasis, and an in-depth evaluation of pancreatic islets and beta cells from these animals revealed intracellular $\mathrm{Ca}^{2+}$ leak via oxidized and Cys-nitrosylated RyR2 channels, depleted intracellular $\mathrm{Ca}^{2+}$ stores, activated ER stress response, mitochondrial malfunction, and decreased fuel-stimulated insulin release [5].

We also verified the effects of pharmacological inhibition of intracellular $\mathrm{Ca}^{2+}$ leak in CPVT-associated RyR2expressing mice, in human islets from diabetic patients, and in an established murine model of T2DM [5]. Our results suggest a scenario in which the chronic ER $\mathrm{Ca}^{2+}$ leak via RyR2 triggers ER stress and mitochondrial dysfunction in pancreatic beta cells, causing a bioenergetic deficit with decreased ATP synthesis, thereby impairing metabolismsecretion coupling. These findings raise the possibility that the relationship between diabetes and cardiovascular disorders may be more complex than previously appreciated: indeed, diabetes, which is a critical risk factor for the development of cardiovascular disease [263], can also represent a sequela of heart disease, especially considering that RyR2 channels are chronically leaky in HF [264].

$\mathrm{Ca}^{2+}$ handling plays a key role in the regulation of glucose homeostasis also in the liver, as evidenced by the observations that glucagon and cAMP can increase $\left[\mathrm{Ca}^{2+}\right]$, promoting gluconeogenesis, while $\mathrm{Ca}^{2+}$ chelation blocks it [265]. We have demonstrated that IP3R1 mediates the fasting-mediated activation of CaMKII in hepatocytes [266]. Moreover, PKA-dependent phosphorylation of IP3R1 has been shown to increase cytosolic $\left[\mathrm{Ca}^{2+}\right]$, leading to increase in the phosphatase activity of calcineurin and the subsequent dephosphorylation of the cAMP response element-binding protein (CREB)-regulated transcription coactivator 2 (CRTC2), thereby resulting in the induction of gluconeogenic gene expression [267]. On the other side, insulindependent phosphorylation of IP3R1 by AKT inhibits $\mathrm{Ca}^{2+}$ mobilization and CRTC2 dephosphorylation, resulting in the suppression of gluconeogenesis [267]. An intriguing role for both RyR and IP3R in the regulation of insulin signaling has been reported in skeletal muscle primary cultures. Specifically, insulin promotes RyR1 $S$-glutathionylation and subsequent RyR1-mediated $\mathrm{Ca}^{2+}$ release; in parallel, insulin stimulates $\mathrm{IP}_{3}$ generation and activation of IP3R-mediated $\mathrm{Ca}^{2+}$ release [268]. These two signaling pathways have been shown to contribute to the net gain in surface GLUT4 levels elicited by insulin [268], increasing glucose uptake [269].

\section{AGING}

A well-established hallmark of aging is the progressive decline in muscle function, characterized by loss of muscle mass and reduced force generating capacity [109]. Progressive development of muscle dysfunction has been described 
not only in mammals $[270,271]$ but also in the nematode Caenorhabditis elegans [272, 273].

E-C uncoupling is considered a major factor in agedependent decline in muscle contraction. Indeed, reduced SR $\mathrm{Ca}^{2+}$ release has been elegantly demonstrated in aged rat gastrocnemii [274], without any significant effect on RyR1 levels [275]. A subsequent study, while confirming no overall effect of age (2-year-old rats) on RyR1 expression in the skeletal muscle, revealed a significant decrease in calstabin 1 levels [276].

We recently proved that RyR 1 in muscle become progressively oxidized, nitrosylated, and depleted of calstabin1, resulting in leaky channels, reduced tetanic $\mathrm{Ca}^{2+}$, decreased muscle specific force and impaired exercise capacity [47]. To confirm that leaky RyR1 causes the defects in function observed in aged muscle we generated a leaky RyR1 model (RyR1-S2844D mouse), which mimics a constitutively phosphorylated state of the channel; we also investigated muscle specific calstabin1 deficient mice. Both strains prematurely develop a skeletal muscle phenotype similar to that observed in 24-month-old WT mice [47].

We provided evidence for a direct role of mitochondrial free radicals in promoting the pathological intracellular $\mathrm{Ca}^{2+}$ leak that underlies age-dependent loss of muscle function [188]. To investigate in detail the effects of mitochondrial anti-oxidative capacity on age-dependent skeletal muscle dysfunction and $\mathrm{Ca}^{2+}$ signaling we used a genetic model with enhanced mitochondrial anti-oxidant activity, in which the human catalase gene is targeted to and overexpressed in mitochondria. Mitochondrial overexpression of catalase resulted in reduced mitochondrial ROS levels, improved both whole organism (exercise capacity), and skeletal muscle (specific force) performance, and prevented age-related reduction in $\mathrm{Ca}^{2+}$ transients, also diminishing $\mathrm{SR} \mathrm{Ca}^{2+}$ leak and age-dependent biochemical modifications of RyR1 [188].

In the heart, aging causes several structural modifications, even in the absence of overt cardiovascular disease. Albeit contractility at rest does not appear to be affected by age, the ability to increase ejection fraction during exercise declines in elderly, and relaxation is impaired in aged individuals compared to younger adults suggesting a blunted cardiac reserve [107]. In particular, aging results in significant biochemical and physiological changes in the E-C machinery.

The amount of $\mathrm{Ca}^{2+}$ delivered to the cytoplasm and the rate of $\mathrm{Ca}^{2+}$ removal are two of the major factors determining the rate, intensity and duration of myocyte contraction [35]. Since cardiac contraction largely reflects the magnitude and time course of increases in cytosolic $\mathrm{Ca}^{2+}$ (i.e. $\mathrm{Ca}^{2+}$ transients), processes affecting $\mathrm{Ca}^{2+}$ transients have been of interest when investigating the impact of age on cardiac contractile function. Several studies have focused on the effect of aging on contraction and $\mathrm{Ca}^{2+}$ homeostasis at the level of the individual ventricular myocyte.

Aged cardiomyocytes typically exhibit a decrease in their ability to augment contractions and $\mathrm{Ca}^{2+}$ transients following $\beta \mathrm{AR}$ stimulation, and the rates of decay of contractions and $\mathrm{Ca}^{2+}$ transients are prolonged [35, 277]. This may be attributed at least in part to an age-related reduced catecholamine sensitivity and impaired $\beta A R$ signaling $[109,113]$. The ability of individual ventricular myocytes to contract declines with age. Indeed, when cardiomyocytes are paced at slow stimulation rates $(<1 \mathrm{~Hz})$, peak contractions appear similar in young adult and aged myocytes from rodents [278]. However at higher, more physiological stimulation frequencies, the extent of cell shortening is lower in aged mouse ventricular myocytes than in young adult cells. Furthermore, re-lengthening is prolonged in aged myocytes [278], which also produce much smaller increases in peak $\mathrm{Ca}^{2+}$ transients than younger cells when myocytes are paced at rapid rates [279].

We have demonstrated in vivo that constitutive phosphorylation of RyR2 at $\operatorname{Ser}^{2808}$ (RyR2-S2808D mice) leads to a characteristic age-related cardiac dysfunction [41]. Indeed, serial echocardiographic measurements over the course of a year revealed that transgenic mice exhibited progressive, age-dependent cardiac dysfunction, manifested as a reduction in ejection fraction, coupled with an increase in left ventricular diameter. Similarly, cardiac catheterization at 1, 2, 6, and 12 months of age revealed a gradual deterioration of myocardial contractility in RyR2-S2808D mice that was not evident in WT littermates [41]. We also observed significant decreases in the levels of PDE4D3, PP1, PP2A, and calstabin2 in the RyR2 macromolecular complex by 6 to 12 months of age, consistent with development of myocardial dysfunction. Furthermore, RyR2-S2808D mice displayed age-associated increases in both Cys-nitrosylation and oxidation of cardiac RyR2, which contribute to the age-dependent depletion of calstabin2 from the RyR2 complex in these mice. Similar post-translational modifications have been found in patients with end-stage $\mathrm{HF}$ and in mice with postischemic HF [41, 105].

More recently, we characterized the cardiac phenotype of calstabin2 $\mathrm{KO}$ mice, revealing an age-associated impaired cardiac function compared to WT littermates, accompanied by augmented cardiac fibrosis, cell death, and shorter telomeres. We also demonstrated that calstabin2 deletion resulted in activation of the AKT/mTOR pathway, upregulation of microRNA-34, and impaired autophagy in the heart [35], all established hallmarks of aging [280].

The role of IP3Rs in aging remains elusive, with reports of its involvement in the regulation of C. elegans lifespan [273] and other studies in mammals investigating its association with neurodegenerative disorders, as discussed in the dedicated section.

\section{CONFLICT OF INTEREST}

Dr. Andrew R. Marks, MD is a consultant and member of the board of ARMGO that is targeting RyR channels for therapeutic purposes.

\section{ACKNOWLEDGEMENTS}

Dr. Gaetano Santulli, MD, PhD is supported by the American Heart Association (AHA: 13POST16810041 and $15 \mathrm{SDG} 25300007)$. Work presented in this article was supported by the NIH (R01-HL102040, R01-HL061503, R01AR060037) and Leducq Foundation. 


\section{REFERENCES}

[1] Marks, A. R. Intracellular calcium-release channels: regulators of cell life and death. Am. J. Physiol., 1997, 272, H597-605.

[2] Rosemblit, N.; Moschella, M. C.; Ondriasa, E.; Gutstein, D. E.; Ondrias, K.; Marks, A. R. Intracellular calcium release channel expression during embryogenesis. Dev. Biol., 1999, 206, 163-177.

[3] Whyte, M. K.; Hardwick, S. J.; Meagher, L. C.; Savill, J. S.; Haslett, C. Transient elevations of cytosolic free calcium retard subsequent apoptosis in neutrophils in vitro. J. Clin. Invest., 1993, $92,446-455$

[4] Hong, C. Y.; Chiang, B. N.; Turner, P. Calcium ion is the key regulator of human sperm function. Lancet, 1984, 2, 1449-1451.

[5] Santulli, G.; Pagano, G.; Sardu, C.; Xie, W.; Reiken, S.; D'Ascia, S. L.; Cannone, M.; Marziliano, N.; Trimarco, B.; Guise, T. A.; Lacampagne, A.; Marks, A. R. Calcium release channel RyR2 regulates insulin release and glucose homeostasis. J. Clin. Invest., 2015, 125, 1968-1978.

[6] Ringer, S. A further Contribution regarding the influence of the different Constituents of the Blood on the Contraction of the Heart. J. Physiol., 1883, 4, 29-42.

[7] Zetterstrom, R.; Arnhold, R. G. Impaired calcium-phosphate homeostasis in newborn infants of diabetic mothers. Acta Paediatr., 1958, 47, 107-112.

[8] Jayaraman, T.; Marks, A. R. Calcineurin is downstream of the inositol 1,4,5-trisphosphate receptor in the apoptotic and cell growth pathways. J. Biol. Chem., 2000, 275, 6417-6420.

[9] Blaustein, M. P. Physiological effects of endogenous ouabain: control of intracellular $\mathrm{Ca}^{2+}$ stores and cell responsiveness. Am. J. Physiol., 1993, 264, C1367-1387.

[10] Chen, S.; Novick, P.; Ferro-Novick, S. ER structure and function. Curr. Opin. Cell Biol., 2013, 25, 428-433.

[11] Brochet, D. X.; Yang, D.; Di Maio, A.; Lederer, W. J.; FranziniArmstrong, C.; Cheng, H. Ca ${ }^{2+}$ blinks: rapid nanoscopic store calcium signaling. Proc. Natl. Acad. Sci. U. S. A., 2005, 102, 30993104.

[12] Flucher, B. E.; Andrews, S. B.; Fleischer, S.; Marks, A. R.; Caswell, A.; Powell, J. A. Triad formation: organization and function of the sarcoplasmic reticulum calcium release channel and triadin in normal and dysgenic muscle in vitro. J. Cell Biol., 1993, 123, 1161-1174.

[13] Park, S. H.; Zhu, P. P.; Parker, R. L.; Blackstone, C. Hereditary spastic paraplegia proteins REEP1, spastin, and atlastin-1 coordinate microtubule interactions with the tubular ER network. J. Clin. Invest., 2010, 120, 1097-1110.

[14] Xu, C.; Bailly-Maitre, B.; Reed, J. C. Endoplasmic reticulum stress: cell life and death decisions. J. Clin. Invest., 2005, 115, 2656-2664.

[15] Lackner, L. L.; Ping, H.; Graef, M.; Murley, A.; Nunnari, J. Endoplasmic reticulum-associated mitochondria-cortex tether functions in the distribution and inheritance of mitochondria. Proc. Natl. Acad. Sci. U. S. A., 2013, 110, E458-467.

[16] Go, L. O.; Moschella, M. C.; Watras, J.; Handa, K. K.; Fyfe, B. S.; Marks, A. R. Differential regulation of two types of intracellular calcium release channels during end-stage heart failure. J. Clin. Invest., 1995, 95, 888-894.

[17] Zalk, R.; Clarke, O. B.; des Georges, A.; Grassucci, R. A.; Reiken, S.; Mancia, F.; Hendrickson, W. A.; Frank, J.; Marks, A. R. Structure of a mammalian ryanodine receptor. Nature, 2015, 517, 44-49.

[18] Cai, X.; Clapham, D. E. Ancestral $\mathrm{Ca}^{2+}$ signaling machinery in early animal and fungal evolution. Mol. Biol. Evol., 2012, 29, 91100.

[19] Liu, Y.; Li, C.; Gao, J.; Wang, W.; Huang, L.; Guo, X.; Li, B.; Wang, J. Comparative characterization of two intracellular $\mathrm{Ca}(2+)-$ release channels from the red flour beetle, Tribolium castaneum. Sci. Rep., 2014, 4, 6702

[20] Harnick, D. J.; Jayaraman, T.; Ma, Y.; Mulieri, P.; Go, L. O.; Marks, A. R. The human type 1 inositol 1,4,5-trisphosphate receptor from T lymphocytes. Structure, localization, and tyrosine phosphorylation. J. Biol. Chem., 1995, 270, 2833-2840.

[21] Marks, A. R.; Tempst, P.; Hwang, K. S.; Taubman, M. B.; Inui, M.; Chadwick, C.; Fleischer, S.; Nadal-Ginard, B. Molecular cloning and characterization of the ryanodine receptor/junctional channel complex cDNA from skeletal muscle sarcoplasmic reticulum. Proc. Natl. Acad. Sci. U. S. A., 1989, 86, 8683-8687.
Brillantes, A. M.; Bezprozvannaya, S.; Marks, A. R. Developmental and tissue-specific regulation of rabbit skeletal and cardiac muscle calcium channels involved in excitation-contraction coupling. Circ. Res., 1994, 75, 503-510.

[23] Marks, A. R.; Fleischer, S.; Tempst, P. Surface topography analysis of the ryanodine receptor/junctional channel complex based on proteolysis sensitivity mapping. J. Biol. Chem., 1990, 265, 1314313149 .

[24] Otsu, K.; Willard, H. F.; Khanna, V. K.; Zorzato, F.; Green, N. M. MacLennan, D. H. Molecular cloning of cDNA encoding the $\mathrm{Ca}^{2+}$ release channel (ryanodine receptor) of rabbit cardiac muscle sarcoplasmic reticulum. J. Biol. Chem., 1990, 265, 13472-13483.

[25] Awad, S. S.; Lamb, H. K.; Morgan, J. M.; Dunlop, W.; Gillespie, J. I. Differential expression of ryanodine receptor RyR2 mRNA in the non-pregnant and pregnant human myometrium. Biochem. J., 1997, 322 (Pt 3), 777-783

[26] Nakashima, Y.; Nishimura, S.; Maeda, A.; Barsoumian, E. L.; Hakamata, Y.; Nakai, J.; Allen, P. D.; Imoto, K.; Kita, T. Molecular cloning and characterization of a human brain ryanodine receptor. FEBS Lett., 1997, 417, 157-162.

[27] Zhang, L.; Liu, Y.; Song, F.; Zheng, H.; Hu, L.; Lu, H.; Liu, P.; Hao, X.; Zhang, W.; Chen, K. Functional SNP in the microRNA367 binding site in the 3'UTR of the calcium channel ryanodine receptor gene 3 (RYR3) affects breast cancer risk and calcification. Proc. Natl. Acad. Sci. U. S. A., 2011, 108, 13653-13658.

[28] Rogers, E. F.; Koniuszy, F. R.; et al. Plant insecticides; ryanodine, a new alkaloid from Ryania speciosa Vahl. J. Am. Chem. Soc., 1948, 70, 3086-3088.

[29] Fairhurst, A. S.; Hasselbach, W. Calcium efflux from a heavy sarcotubular fraction. Effects of ryanodine, caffeine and magnesium. Eur. J. Biochem., 1970, 13, 504-509.

[30] Copello, J. A.; Barg, S.; Onoue, H.; Fleischer, S. Heterogeneity of $\mathrm{Ca}^{2+}$ gating of skeletal muscle and cardiac ryanodine receptors. Biophys. J., 1997, 73, 141-156.

[31] Laver, D. R.; Roden, L. D.; Ahern, G. P.; Eager, K. R.; Junankar, P. R.; Dulhunty, A. F. Cytoplasmic $\mathrm{Ca}^{2+}$ inhibits the ryanodine receptor from cardiac muscle. J. Membr. Biol., 1995, 147, 7-22.

[32] Marks, A. R.; Marx, S. O.; Reiken, S. Regulation of ryanodine receptors via macromolecular complexes: a novel role for leucine/isoleucine zippers. Trends Cardiovasc. Med., 2002, 12, 166-170.

[33] Timerman, A. P.; Ogunbumni, E.; Freund, E.; Wiederrecht, G.; Marks, A. R.; Fleischer, S. The calcium release channel of sarcoplasmic reticulum is modulated by FK-506-binding protein. Dissociation and reconstitution of FKBP-12 to the calcium release channel of skeletal muscle sarcoplasmic reticulum. J. Biol. Chem., 1993, 268, 22992-22999.

[34] Xin, H. B.; Timerman, A. P.; Onoue, H.; Wiederrecht, G. J.; Fleischer, S. Affinity purification of the ryanodine receptor/calcium release channel from fast twitch skeletal muscle based on its tight association with FKBP12. Biochem. Biophys. Res. Commun., 1995, 214, 263-270.

[35] Yuan, Q.; Chen, Z.; Santulli, G.; Gu, L.; Yang, Z. G.; Yuan, Z. Q.; Zhao, Y. T.; Xin, H. B.; Deng, K. Y.; Wang, S. Q.; Ji, G. Functional Role of Calstabin2 in Age-related Cardiac Alterations. Sci. Rep., 2014, 4, 7425.

[36] Brillantes, A. B.; Ondrias, K.; Scott, A.; Kobrinsky, E.; Ondriasova, E.; Moschella, M. C.; Jayaraman, T.; Landers, M.; Ehrlich, B. E.; Marks, A. R. Stabilization of calcium release channel (ryanodine receptor) function by FK506-binding protein. Cell, 1994, 77, 513-523.

[37] Huang, F.; Shan, J.; Reiken, S.; Wehrens, X. H.; Marks, A. R. Analysis of calstabin2 (FKBP12.6)-ryanodine receptor interactions: rescue of heart failure by calstabin 2 in mice. Proc. Natl. Acad. Sci. U. S. A., 2006, 103, 3456-3461.

[38] Marks, A. R. A guide for the perplexed: towards an understanding of the molecular basis of heart failure. Circulation, 2003, 107, 1456-1459.

[39] Marx, S. O.; Reiken, S.; Hisamatsu, Y.; Gaburjakova, M.; Gaburjakova, J.; Yang, Y. M.; Rosemblit, N.; Marks, A. R. Phosphorylation-dependent regulation of ryanodine receptors: a novel role for leucine/isoleucine zippers. J. Cell Biol., 2001, 153, 699-708.

[40] Reiken, S.; Lacampagne, A.; Zhou, H.; Kherani, A.; Lehnart, S. E.; Ward, C.; Huang, F.; Gaburjakova, M.; Gaburjakova, J.; Rosemblit, N.; Warren, M. S.; He, K. L.; Yi, G. H.; Wang, J.; Burkhoff, D.; Vassort, G.; Marks, A. R. PKA phosphorylation activates the 
calcium release channel (ryanodine receptor) in skeletal muscle: defective regulation in heart failure. J. Cell Biol., 2003, 160, 919928.

[41] Shan, J.; Betzenhauser, M. J.; Kushnir, A.; Reiken, S.; Meli, A. C.; Wronska, A.; Dura, M.; Chen, B. X.; Marks, A. R. Role of chronic ryanodine receptor phosphorylation in heart failure and betaadrenergic receptor blockade in mice. J. Clin. Invest., 2010, 120, 4375-4387.

[42] Kushnir, A.; Shan, J.; Betzenhauser, M. J.; Reiken, S.; Marks, A. R. Role of CaMKIIdelta phosphorylation of the cardiac ryanodine receptor in the force frequency relationship and heart failure. Proc. Natl. Acad. Sci. U. S. A., 2010, 107, 10274-10279.

[43] Lehnart, S. E.; Wehrens, X. H.; Reiken, S.; Warrier, S.; Belevych, A. E.; Harvey, R. D.; Richter, W.; Jin, S. L.; Conti, M.; Marks, A. R. Phosphodiesterase 4D deficiency in the ryanodine-receptor complex promotes heart failure and arrhythmias. Cell, 2005, 123, 25-35.

[44] Marx, S. O.; Reiken, S.; Hisamatsu, Y.; Jayaraman, T.; Burkhoff, D.; Rosemblit, N.; Marks, A. R. PKA phosphorylation dissociates FKBP12.6 from the calcium release channel (ryanodine receptor): defective regulation in failing hearts. Cell, 2000, 101, 365-376.

[45] Shan, J.; Kushnir, A.; Betzenhauser, M. J.; Reiken, S.; Li, J.; Lehnart, S. E.; Lindegger, N.; Mongillo, M.; Mohler, P. J.; Marks, A. R. Phosphorylation of the ryanodine receptor mediates the cardiac fight or flight response in mice. J. Clin. Invest., 2010, 120, 4388-4398.

[46] Liu, X.; Betzenhauser, M. J.; Reiken, S.; Meli, A. C.; Xie, W.; Chen, B. X.; Arancio, O.; Marks, A. R. Role of leaky neuronal ryanodine receptors in stress-induced cognitive dysfunction. Cell, 2012, 150, 1055-1067.

[47] Andersson, D. C.; Betzenhauser, M. J.; Reiken, S.; Meli, A. C.; Umanskaya, A.; Xie, W.; Shiomi, T.; Zalk, R.; Lacampagne, A.; Marks, A. R. Ryanodine receptor oxidation causes intracellular calcium leak and muscle weakness in aging. Cell Metab., 2011, 14, 196-207.

[48] Tester, D. J.; Dura, M.; Carturan, E.; Reiken, S.; Wronska, A.; Marks, A. R.; Ackerman, M. J. A mechanism for sudden infant death syndrome (SIDS): stress-induced leak via ryanodine receptors. Heart Rhythm, 2007, 4, 733-739.

[49] Maki, T.; Gruver, E. J.; Davidoff, A. J.; Izzo, N.; Toupin, D.; Colucci, W.; Marks, A. R.; Marsh, J. D. Regulation of calcium channel expression in neonatal myocytes by catecholamines. $J$. Clin. Invest., 1996, 97, 656-663.

[50] Fauconnier, J.; Thireau, J.; Reiken, S.; Cassan, C.; Richard, S.; Matecki, S.; Marks, A. R.; Lacampagne, A. Leaky RyR2 trigger ventricular arrhythmias in Duchenne muscular dystrophy. Proc. Natl. Acad. Sci. U. S. A., 2010, 107, 1559-1564.

[51] Frank, K. F.; Bolck, B.; Ding, Z.; Krause, D.; Hattebuhr, N.; Malik, A.; Brixius, K.; Hajjar, R. J.; Schrader, J.; Schwinger, R. H. Overexpression of sorcin enhances cardiac contractility in vivo and in vitro. J. Mol. Cell. Cardiol., 2005, 38, 607-615.

[52] Meissner, G.; Henderson, J. S. Rapid calcium release from cardiac sarcoplasmic reticulum vesicles is dependent on $\mathrm{Ca}^{2+}$ and is modulated by $\mathrm{Mg} 2+$, adenine nucleotide, and calmodulin. J. Biol. Chem., 1987, 262, 3065-3073.

[53] Feng, W.; Tu, J.; Yang, T.; Vernon, P. S.; Allen, P. D.; Worley, P. F.; Pessah, I. N. Homer regulates gain of ryanodine receptor type 1 channel complex. J. Biol. Chem., 2002, 277, 44722-44730.

[54] Lee, H. G.; Kang, H.; Kim, D. H.; Park, W. J. Interaction of HRC (histidine-rich $\mathrm{Ca}(2+)$-binding protein) and triadin in the lumen of sarcoplasmic reticulum. J. Biol. Chem., 2001, 276, 39533-39538.

[55] Ritterhoff, J.; Volkers, M.; Seitz, A.; Spaich, K.; Gao, E.; Peppel, K.; Pleger, S. T.; Zimmermann, W. H.; Friedrich, O.; Fink, R. H.; Koch, W. J.; Katus, H. A.; Most, P. S100A1 DNA-based inotropic therapy protects against pro-arrhythmogenic ryanodine receptor 2 dysfunction. Mol. Ther., 2015.

[56] Rossi, D.; Bencini, C.; Maritati, M.; Benini, F.; Lorenzini, S.; Pierantozzi, E.; Scarcella, A. M.; Paolini, C.; Protasi, F.; Sorrentino, V. Distinct regions of triadin are required for targeting and retention at the junctional domain of the sarcoplasmic reticulum. Biochem. J., 2014, 458, 407-417.

[57] Zhang, L.; Kelley, J.; Schmeisser, G.; Kobayashi, Y. M.; Jones, L. R. Complex formation between junctin, triadin, calsequestrin, and the ryanodine receptor. Proteins of the cardiac junctional sarcoplasmic reticulum membrane. J. Biol. Chem., 1997, 272, 2338923397.
[58] Ohkura, M.; Furukawa, K.; Fujimori, H.; Kuruma, A.; Kawano, S.; Hiraoka, M.; Kuniyasu, A.; Nakayama, H.; Ohizumi, Y. Dual regulation of the skeletal muscle ryanodine receptor by triadin and calsequestrin. Biochemistry, 1998, 37, 12987-12993.

[59] Bosanac, I.; Alattia, J. R.; Mal, T. K.; Chan, J.; Talarico, S.; Tong, F. K.; Tong, K. I.; Yoshikawa, F.; Furuichi, T.; Iwai, M.; Michikawa, T.; Mikoshiba, K.; Ikura, M. Structure of the inositol 1,4,5trisphosphate receptor binding core in complex with its ligand. $\mathrm{Na}$ ture, 2002, 420, 696-700.

[60] Furuichi, T.; Yoshikawa, S.; Miyawaki, A.; Wada, K.; Maeda, N.; Mikoshiba, K. Primary structure and functional expression of the inositol 1,4,5-trisphosphate-binding protein P400. Nature, 1989, 342, 32-38.

[61] Mignery, G. A.; Sudhof, T. C.; Takei, K.; De Camilli, P. Putative receptor for inositol 1,4,5-trisphosphate similar to ryanodine receptor. Nature, 1989, 342, 192-195.

[62] Marks, A. R.; Tempst, P.; Chadwick, C. C.; Riviere, L.; Fleischer, S.; Nadal-Ginard, B. Smooth muscle and brain inositol 1,4,5trisphosphate receptors are structurally and functionally similar. $J$. Biol. Chem., 1990, 265, 20719-20722.

[63] Nakagawa, T.; Okano, H.; Furuichi, T.; Aruga, J.; Mikoshiba, K. The subtypes of the mouse inositol 1,4,5-trisphosphate receptor are expressed in a tissue-specific and developmentally specific manner. Proc. Natl. Acad. Sci. U. S. A., 1991, 88, 6244-6248.

[64] Vermassen, E.; Parys, J. B.; Mauger, J. P. Subcellular distribution of the inositol 1,4,5-trisphosphate receptors: functional relevance and molecular determinants. Biol. Cell., 2004, 96, 3-17.

[65] Supattapone, S.; Worley, P. F.; Baraban, J. M.; Snyder, S. H. Solubilization, purification, and characterization of an inositol trisphosphate receptor. J. Biol. Chem., 1988, 263, 1530-1534.

[66] Narayanan, D.; Adebiyi, A.; Jaggar, J. H. Inositol trisphosphate receptors in smooth muscle cells. Am. J. Physiol. Heart Circ. Physiol., 2012, 302, H2190-2210.

[67] deSouza, N.; Cui, J.; Dura, M.; McDonald, T. V.; Marks, A. R. A function for tyrosine phosphorylation of type 1 inositol 1,4,5trisphosphate receptor in lymphocyte activation. J. Cell Biol., 2007, 179, 923-934.

[68] Klar, J.; Hisatsune, C.; Baig, S. M.; Tariq, M.; Johansson, A. C.; Rasool, M.; Malik, N. A.; Ameur, A.; Sugiura, K.; Feuk, L.; Mikoshiba, K.; Dahl, N. Abolished InsP3R2 function inhibits sweat secretion in both humans and mice. J. Clin. Invest., 2014, 124, 47734780.

[69] De Smedt, H.; Missiaen, L.; Parys, J. B.; Henning, R. H.; Sienaert, I.; Vanlingen, S.; Gijsens, A.; Himpens, B.; Casteels, R. Isoform diversity of the inositol trisphosphate receptor in cell types of mouse origin. Biochem. J., 1997, 322 (Pt 2), 575-583.

[70] Missiaen, L.; Parys, J. B.; De Smedt, H.; Sienaert, I.; Henning, R. H.; Casteels, R. Opening up $\mathrm{Ca}^{2+}$ stores with InsP3. Nature, 1995 376, 299-300; author reply 301.

[71] Jayaraman, T.; Ondriasova, E.; Ondrias, K.; Harnick, D. J.; Marks, A. R. The inositol 1,4,5-trisphosphate receptor is essential for Tcell receptor signaling. Proc. Natl. Acad. Sci. U. S. A., 1995, 92, 6007-6011.

[72] Suzuki, T.; Imai, J.; Yamada, T.; Ishigaki, Y.; Kaneko, K.; Uno, K.; Hasegawa, Y.; Ishihara, H.; Oka, Y.; Katagiri, H. Interleukin-6 enhances glucose-stimulated insulin secretion from pancreatic betacells: potential involvement of the PLC-IP3-dependent pathway. Diabetes, 2011, 60, 537-547.

[73] Jayaraman, T.; Ondrias, K.; Ondriasova, E.; Marks, A. R. Regulation of the inositol 1,4,5-trisphosphate receptor by tyrosine phosphorylation. Science, 1996, 272, 1492-1494.

[74] Sienaert, I.; Nadif Kasri, N.; Vanlingen, S.; Parys, J. B.; Callewaert, G.; Missiaen, L.; de Smedt, H. Localization and function of a calmodulin-apocalmodulin-binding domain in the $\mathrm{N}$-terminal part of the type 1 inositol 1,4,5-trisphosphate receptor. Biochem. J., 2002, 365, 269-277.

[75] Yang, J.; McBride, S.; Mak, D. O.; Vardi, N.; Palczewski, K.; Haeseleer, F.; Foskett, J. K. Identification of a family of calcium sensors as protein ligands of inositol trisphosphate receptor $\mathrm{Ca}(2+)$ release channels. Proc. Natl. Acad. Sci. U. S. A., 2002, 99, 77117716.

[76] Hirota, J.; Ando, H.; Hamada, K.; Mikoshiba, K. Carbonic anhydrase-related protein is a novel binding protein for inositol 1,4,5trisphosphate receptor type 1. Biochem. J., 2003, 372, 435-441.

[77] Joseph, S. K.; Samanta, S. Detergent solubility of the inositol trisphosphate receptor in rat brain membranes. Evidence for asso- 
ciation of the receptor with ankyrin. J. Biol. Chem., 1993, 268, 6477-6486.

[78] Tu, J. C.; Xiao, B.; Yuan, J. P.; Lanahan, A. A.; Leoffert, K.; Li, M.; Linden, D. J.; Worley, P. F. Homer binds a novel proline-rich motif and links group 1 metabotropic glutamate receptors with IP3 receptors. Neuron, 1998, 21, 717-726.

[79] Choe, C. U.; Ehrlich, B. E. The inositol 1,4,5-trisphosphate receptor (IP3R) and its regulators: sometimes good and sometimes bad teamwork. Sci. STKE, 2006, 2006, re 15.

[80] Rong, Y. P.; Aromolaran, A. S.; Bultynck, G.; Zhong, F.; Li, X.; McColl, K.; Matsuyama, S.; Herlitze, S.; Roderick, H. L.; Bootman, M. D.; Mignery, G. A.; Parys, J. B.; De Smedt, H.; Distelhorst, C. W. Targeting Bcl-2-IP3 receptor interaction to reverse Bcl-2's inhibition of apoptotic calcium signals. Mol. Cell, 2008, 31, 255-265.

[81] Akl, H.; Monaco, G.; La Rovere, R.; Welkenhuyzen, K.; Kiviluoto, S.; Vervliet, T.; Molgo, J.; Distelhorst, C. W.; Missiaen, L.; Mikoshiba, K.; Parys, J. B.; De Smedt, H.; Bultynck, G. IP3R2 levels dictate the apoptotic sensitivity of diffuse large B-cell lymphoma cells to an IP3R-derived peptide targeting the BH4 domain of Bcl2. Cell Death Dis., 2013, 4, e632.

[82] Vervliet, T.; Decrock, E.; Molgo, J.; Sorrentino, V.; Missiaen, L.; Leybaert, L.; De Smedt, H.; Kasri, N. N.; Parys, J. B.; Bultynck, G. Bcl-2 binds to and inhibits ryanodine receptors. J. Cell Sci., 2014, 127, 2782-2792

[83] Ando, H.; Mizutani, A.; Kiefer, H.; Tsuzurugi, D.; Michikawa, T.; Mikoshiba, K. IRBIT suppresses IP3 receptor activity by competing with IP3 for the common binding site on the IP3 receptor. Mol. Cell, 2006, 22, 795-806.

[84] Hamada, K.; Miyata, T.; Mayanagi, K.; Hirota, J.; Mikoshiba, K. Two-state conformational changes in inositol 1,4,5-trisphosphate receptor regulated by calcium. J. Biol. Chem., 2002, 277, 2111521118

[85] Ferris, C. D.; Huganir, R. L.; Bredt, D. S.; Cameron, A. M.; Snyder, S. H. Inositol trisphosphate receptor: phosphorylation by protein kinase $\mathrm{C}$ and calcium calmodulin-dependent protein kinases in reconstituted lipid vesicles. Proc. Natl. Acad. Sci. U. S. A., 1991, 88, 2232-2235.

[86] DeSouza, N.; Reiken, S.; Ondrias, K.; Yang, Y. M.; Matkovich, S.; Marks, A. R. Protein kinase A and two phosphatases are components of the inositol 1,4,5-trisphosphate receptor macromolecular signaling complex. J. Biol. Chem., 2002, 277, 39397-39400.

[87] Cameron, A. M.; Steiner, J. P.; Sabatini, D. M.; Kaplin, A. I.; Walensky, L. D.; Snyder, S. H. Immunophilin FK506 binding protein associated with inositol 1,4,5-trisphosphate receptor modulates calcium flux. Proc. Natl. Acad. Sci. U. S. A., 1995, 92, 1784-1788.

[88] Bultynck, G.; De Smet, P.; Rossi, D.; Callewaert, G.; Missiaen, L.; Sorrentino, V.; De Smedt, H.; Parys, J. B. Characterization and mapping of the $12 \mathrm{kDa}$ FK506-binding protein (FKBP12)-binding site on different isoforms of the ryanodine receptor and of the inositol 1,4,5-trisphosphate receptor. Biochem. J., 2001, 354, 413422.

[89] Bultynck, G.; Rossi, D.; Callewaert, G.; Missiaen, L.; Sorrentino, V.; Parys, J. B.; De Smedt, H. The conserved sites for the FK506binding proteins in ryanodine receptors and inositol 1,4,5trisphosphate receptors are structurally and functionally different. J. Biol. Chem., 2001, 276, 47715-47724.

[90] Reuter, H.; Beeler, G. W., Jr. Calcium current and activation of contraction in ventricular myocardial fibers. Science, 1969, 163, $399-401$

[91] Trautwein, W.; Kassebaum, D. G. On the mechanism of spontaneous impulse generation in the pacemaker of the heart. J. Gen. Physiol., 1961, 45, 317-330.

[92] Reuter, H. The dependence of slow inward current in Purkinje fibres on the extracellular calcium-concentration. J. Physiol., 1967, 192, 479-492.

[93] Galvani, L. De viribus electricitatis in motu musculari commentarius. De Bononiensi Scientiarum et Artium Instituto atque Academia Commentarii, 1791, 7, 363-418.

[94] Mines, G. R. On functional analysis by the action of electrolytes. $J$. Physiol., 1913, 46, 188-235.

[95] Winegrad, S.; Shanes, A. M. Calcium flux and contractility in guinea pig atria. J. Gen. Physiol., 1962, 45, 371-394.

[96] Fabiato, A.; Fabiato, F. Calcium and cardiac excitation-contraction coupling. Annu. Rev. Physiol., 1979, 41, 473-484.
[97] Santulli, G.; Wronska, A.; Uryu, K.; Diacovo, T. G.; Gao, M.; Marx, S. O.; Kitajewski, J.; Chilton, J. M.; Akat, K. M.; Tuschl, T.; Marks, A. R.; Totary-Jain, H. A selective microRNA-based strategy inhibits restenosis while preserving endothelial function. $J$. Clin. Invest., 2014, 124, 4102-4114.

[98] Santulli, G. Epidemiology of cardiovascular disease in the $21^{\text {st }}$ century: Updated numbers and updated facts. Journal of Cardiovascular Disease - JCvD, 2013, 1, 1-2.

[99] Wronska, A.; Kurkowska-Jastrzebska, I.; Santulli, G. Application of microRNAs in diagnosis and treatment of cardiovascular disease. Acta Physiol., 2015, 213, 60-83.

[100] Santulli, G. Coronary heart disease risk factors and mortality. JAMA, 2012, 307, 1137.

[101] D'Ascia, S. L.; D'Ascia, C.; Marino, V.; Lombardi, A.; Santulli, R.; Chiariello, M.; Santulli, G. Cardiac resynchronisation therapy response predicts occurrence of atrial fibrillation in non-ischaemic dilated cardiomyopathy. Int. J. Clin. Pract., 2011, 65, 1149-1155.

[102] Santulli, G.; Campanile, A.; Spinelli, L.; Assante di Panzillo, E.; Ciccarelli, M.; Trimarco, B.; Iaccarino, G. G protein-coupled receptor kinase 2 in patients with acute myocardial infarction. Am. $J$. Cardiol., 2011, 107, 1125-1130.

[103] Pieske, B.; Maier, L. S.; Schmidt-Schweda, S. Sarcoplasmic reticulum $\mathrm{Ca}^{2+}$ load in human heart failure. Basic Res. Cardiol., 2002, 97 Suppl 1, I63-71.

[104] Reiken, S.; Gaburjakova, M.; Guatimosim, S.; Gomez, A. M.; D'Armiento, J.; Burkhoff, D.; Wang, J.; Vassort, G.; Lederer, W. J.; Marks, A. R. Protein kinase A phosphorylation of the cardiac calcium release channel (ryanodine receptor) in normal and failing hearts. Role of phosphatases and response to isoproterenol. J. Biol. Chem., 2003, 278, 444-453.

[105] Santulli, G.; Xie, W.; Reiken, S. R.; Marks, A. R. Mitochondrial calcium overload is a key determinant in heart failure. Proc. Natl. Acad. Sci. U. S. A., 2015, In press.

[106] Santulli, G. The Adrenergic System in Cardiovascular Metabolism and Aging. In: The Cardiovascular Adrenergic System (Editor: Lymperopoulos, A.) 2015, 97-118.

[107] Santulli, G.; Ciccarelli, M.; Trimarco, B.; Iaccarino, G. Physical activity ameliorates cardiovascular health in elderly subjects: the functional role of the beta adrenergic system. Front. Physiol., 2013 , 4, 209.

[108] Lymperopoulos, A.; Rengo, G.; Koch, W. J. Adrenergic nervous system in heart failure: pathophysiology and therapy. Circ. Res., 2013, 113, 739-753.

[109] Santulli, G.; Iaccarino, G. Pinpointing beta adrenergic receptor in ageing pathophysiology: victim or executioner? Evidence from crime scenes. Immun. Ageing, 2013, 10, 10 .

[110] Perino, A.; Ghigo, A.; Ferrero, E.; Morello, F.; Santulli, G.; Baillie, G. S.; Damilano, F.; Dunlop, A. J.; Pawson, C.; Walser, R.; Levi, R.; Altruda, F.; Silengo, L.; Langeberg, L. K.; Neubauer, G.; Heymans, S.; Lembo, G.; Wymann, M. P.; Wetzker, R.; Houslay, M. D.; Iaccarino, G.; Scott, J. D.; Hirsch, E. Integrating cardiac PIP3 and cAMP signaling through a PKA anchoring function of p110gamma. Mol. Cell, 2011, 42, 84-95.

[111] Santulli, G. Sympathetic nervous system signaling in heart failure and cardiac aging. In: Pathophysiology and Pharmacotherapy of Cardiovascular Disease (Editors: Jagadeesh G, Balakumar P, Khin M) 2015, 83-105.

[112] Santulli, G. Beta-blockers in diabetic patients with heart failure JAMA Intern Med., 2015, 175, 657.

[113] Santulli, G.; Trimarco, B.; Iaccarino, G. G-protein-coupled receptor kinase 2 and hypertension: molecular insights and pathophysiological mechanisms. High Blood Press. Cardiovasc. Prev., 2013, 20, 512.

[114] Lowes, B. D.; Gilbert, E. M.; Abraham, W. T.; Minobe, W. A.; Larrabee, P.; Ferguson, D.; Wolfel, E. E.; Lindenfeld, J.; Tsvetkova, T.; Robertson, A. D.; Quaife, R. A.; Bristow, M. R. Myocardial gene expression in dilated cardiomyopathy treated with beta-blocking agents. N. Engl. J. Med., 2002, 346, 1357-1365.

[115] Reiken, S.; Gaburjakova, M.; Gaburjakova, J.; He Kl, K. L.; Prieto, A.; Becker, E.; Yi Gh, G. H.; Wang, J.; Burkhoff, D.; Marks, A. R. beta-adrenergic receptor blockers restore cardiac calcium release channel (ryanodine receptor) structure and function in heart failure. Circulation, 2001, 104, 2843-2848.

[116] Reiken, S.; Wehrens, X. H.; Vest, J. A.; Barbone, A.; Klotz, S.; Mancini, D.; Burkhoff, D.; Marks, A. R. Beta-blockers restore calcium release channel function and improve cardiac muscle per- 
formance in human heart failure. Circulation, 2003, 107, 24592466.

[117] Fischer, T. H.; Herting, J.; Tirilomis, T.; Renner, A.; Neef, S.; Toischer, K.; Ellenberger, D.; Forster, A.; Schmitto, J. D.; Gummert, J.; Schondube, F. A.; Hasenfuss, G.; Maier, L. S.; Sossalla, S. $\mathrm{Ca}^{2+} /$ calmodulin-dependent protein kinase II and protein kinase A differentially regulate sarcoplasmic reticulum $\mathrm{Ca}^{2+}$ leak in human cardiac pathology. Circulation, 2013, 128, 970-981.

[118] Bowditch, H. Über die Eigentümlichkeiten der Reizbarkeit, welche die Muskelfasern des Herzens zeigen. Berichte über die Verhandlungen der Königlich Sächsischen Gesellschaft zu Leipzig; Mathematisch-Physische Classe, 1871, 652-689.

[119] Ling, H.; Zhang, T.; Pereira, L.; Means, C. K.; Cheng, H.; Gu, Y.; Dalton, N. D.; Peterson, K. L.; Chen, J.; Bers, D.; Brown, J. H. Requirement for $\mathrm{Ca}^{2+} /$ calmodulin-dependent kinase II in the transition from pressure overload-induced cardiac hypertrophy to heart failure in mice. J. Clin. Invest., 2009, 119, 1230-1240.

[120] He, B. J.; Joiner, M. L.; Singh, M. V.; Luczak, E. D.; Swaminathan, P. D.; Koval, O. M.; Kutschke, W.; Allamargot, C.; Yang, J.; Guan, X.; Zimmerman, K.; Grumbach, I. M.; Weiss, R. M.; Spitz, D. R.; Sigmund, C. D.; Blankesteijn, W. M.; Heymans, S.; Mohler, P. J.; Anderson, M. E. Oxidation of CaMKII determines the cardiotoxic effects of aldosterone. Nat. Med., 2011, 17, 1610-1618.

[121] Ho, H. T.; Liu, B.; Snyder, J. S.; Lou, Q.; Brundage, E. A.; VelezCortes, F.; Wang, H.; Ziolo, M. T.; Anderson, M. E.; Sen, C. K.; Wehrens, X. H.; Fedorov, V. V.; Biesiadecki, B. J.; Hund, T. J.; Gyorke, S. Ryanodine receptor phosphorylation by oxidized CaMKII contributes to the cardiotoxic effects of cardiac glycosides. Cardiovasc. Res., 2014, 101, 165-174.

[122] Song, L.; Alcalai, R.; Arad, M.; Wolf, C. M.; Toka, O.; Conner, D. A.; Berul, C. I.; Eldar, M.; Seidman, C. E.; Seidman, J. G. Calsequestrin 2 (CASQ2) mutations increase expression of calreticulin and ryanodine receptors, causing catecholaminergic polymorphic ventricular tachycardia. J. Clin. Invest., 2007, 117, 1814-1823.

[123] Xie, W.; Santulli, G.; Reiken, S.; Yuan, Q.; Osborne, B.; Chen, B.; Marks, A. R. Mitochondrial oxidative stress promotes atrial fibrillation. Sci. Rep., 2015, In press.

[124] Shan, J.; Xie, W.; Betzenhauser, M.; Reiken, S.; Chen, B. X.; Wronska, A.; Marks, A. R. Calcium leak through ryanodine receptors leads to atrial fibrillation in 3 mouse models of catecholaminergic polymorphic ventricular tachycardia. Circ. Res., 2012, $111,708-717$.

[125] Xie, W.; Santulli, G.; Guo, X.; Gao, M.; Chen, B. X.; Marks, A. R. Imaging atrial arrhythmic intracellular calcium in intact heart. $J$. Mol. Cell. Cardiol., 2013, 64, 120-123.

[126] Cheng, Y.; Zhan, Q.; Zhao, J.; Xiao, J. Stabilizing ryanodine receptor type 2: a novel strategy for the treatment of atrial fibrillation. Med. Sci. Monit., 2010, 16, HY23-26.

[127] Vinet, L.; Pezet, M.; Bito, V.; Briec, F.; Biesmans, L.; RouetBenzineb, P.; Gellen, B.; Previlon, M.; Chimenti, S.; Vilaine, J. P.; Charpentier, F.; Sipido, K. R.; Mercadier, J. J. Cardiac FKBP12.6 overexpression protects against triggered ventricular tachycardia in pressure overloaded mouse hearts. Basic Res. Cardiol., 2012, 107, 246.

[128] Marks, A. R.; Priori, S.; Memmi, M.; Kontula, K.; Laitinen, P. J. Involvement of the cardiac ryanodine receptor/calcium release channel in catecholaminergic polymorphic ventricular tachycardia. J. Cell. Physiol., 2002, 190, 1-6.

[129] Rampazzo, A.; Nava, A.; Erne, P.; Eberhard, M.; Vian, E.; Slomp, P.; Tiso, N.; Thiene, G.; Danieli, G. A. A new locus for arrhythmogenic right ventricular cardiomyopathy (ARVD2) maps to chromosome 1q42-q43. Hum. Mol. Genet., 1995, 4, 2151-2154.

[130] Campbell, M. J.; Czosek, R. J.; Hinton, R. B.; Miller, E. M. Exon 3 deletion of ryanodine receptor causes left ventricular noncompaction, worsening catecholaminergic polymorphic ventricular tachycardia, and sudden cardiac arrest. Am. J. Med. Genet. A, 2015.

[131] Wehrens, X. H.; Lehnart, S. E.; Huang, F.; Vest, J. A.; Reiken, S. R.; Mohler, P. J.; Sun, J.; Guatimosim, S.; Song, L. S.; Rosemblit, N.; D'Armiento, J. M.; Napolitano, C.; Memmi, M.; Priori, S. G.; Lederer, W. J.; Marks, A. R. FKBP12.6 deficiency and defective calcium release channel (ryanodine receptor) function linked to exercise-induced sudden cardiac death. Cell, 2003, 113, 829-840.

[132] Mallat, Z.; Tedgui, A.; Fontaliran, F.; Frank, R.; Durigon, M.; Fontaine, G. Evidence of apoptosis in arrhythmogenic right ventricular dysplasia. N. Engl. J. Med., 1996, 335, 1190-1196.
[133] Santulli, G. Classification of syncope-producing cardiac arrhythmias. In: Comas and syncope: causes, prevention and treatment Nova Science Publisher, New York, NY; 2012, 167-177.

[134] Tiso, N.; Stephan, D. A.; Nava, A.; Bagattin, A.; Devaney, J. M.; Stanchi, F.; Larderet, G.; Brahmbhatt, B.; Brown, K.; Bauce, B.; Muriago, M.; Basso, C.; Thiene, G.; Danieli, G. A.; Rampazzo, A. Identification of mutations in the cardiac ryanodine receptor gene in families affected with arrhythmogenic right ventricular cardiomyopathy type 2 (ARVD2). Hum. Mol. Genet., 2001, 10, 189-194.

[135] Asimaki, A.; Tandri, H.; Huang, H.; Halushka, M. K.; Gautam, S.; Basso, C.; Thiene, G.; Tsatsopoulou, A.; Protonotarios, N.; McKenna, W. J.; Calkins, H.; Saffitz, J. E. A new diagnostic test for arrhythmogenic right ventricular cardiomyopathy. N. Engl. J. Med., 2009, 360, 1075-1084.

[136] Sumitomo, N.; Harada, K.; Nagashima, M.; Yasuda, T.; Nakamura Y.; Aragaki, Y.; Saito, A.; Kurosaki, K.; Jouo, K.; Koujiro, M. Konishi, S.; Matsuoka, S.; Oono, T.; Hayakawa, S.; Miura, M.; Ushinohama, H.; Shibata, T.; Niimura, I. Catecholaminergic polymorphic ventricular tachycardia: electrocardiographic characteristics and optimal therapeutic strategies to prevent sudden death Heart, 2003, 89, 66-70.

[137] Lehnart, S. E.; Terrenoire, C.; Reiken, S.; Wehrens, X. H.; Song, L. S.; Tillman, E. J.; Mancarella, S.; Coromilas, J.; Lederer, W. J Kass, R. S.; Marks, A. R. Stabilization of cardiac ryanodine receptor prevents intracellular calcium leak and arrhythmias. Proc. Natl. Acad. Sci. U. S. A., 2006, 103, 7906-7910.

[138] Chelu, M. G.; Sarma, S.; Sood, S.; Wang, S.; van Oort, R. J.; Skapura, D. G.; Li, N.; Santonastasi, M.; Muller, F. U.; Schmitz, W.; Schotten, U.; Anderson, M. E.; Valderrabano, M.; Dobrev, D.; Wehrens, X. H. Calmodulin kinase II-mediated sarcoplasmic reticulum $\mathrm{Ca}^{2+}$ leak promotes atrial fibrillation in mice. J. Clin. Invest., 2009, 119, 1940-1951.

[139] Cooley, N.; Ouyang, K.; McMullen, J. R.; Kiriazis, H.; Sheikh, F.; Wu, W.; Mu, Y.; Du, X. J.; Chen, J.; Woodcock, E. A. No contribution of IP3-R(2) to disease phenotype in models of dilated cardiomyopathy or pressure overload hypertrophy. Circ. Heart Fail., 2013, 6, 318-325.

[140] Moschella, M. C.; Marks, A. R. Inositol 1,4,5-trisphosphate receptor expression in cardiac myocytes. J. Cell Biol., 1993, 120, 1137 1146.

[141] Zima, A. V.; Blatter, L. A. Inositol-1,4,5-trisphosphate-dependent $\mathrm{Ca}(2+)$ signalling in cat atrial excitation-contraction coupling and arrhythmias. J. Physiol., 2004, 555, 607-615.

[142] Taylor, C. W.; Tovey, S. C. IP(3) receptors: toward understanding their activation. Cold Spring Harb. Perspect. Biol., 2010, 2, a004010.

[143] Kentish, J. C.; Barsotti, R. J.; Lea, T. J.; Mulligan, I. P.; Patel, J. R.; Ferenczi, M. A. Calcium release from cardiac sarcoplasmic reticulum induced by photorelease of calcium or $\operatorname{Ins}(1,4,5) \mathrm{P} 3$. Am. J. Physiol., 1990, 258, H610-615.

[144] Hansen, C. A.; Joseph, S. K.; Robishaw, J. D. Ins 1,4,5-P3 and $\mathrm{Ca}^{2+}$ signaling in quiescent neonatal cardiac myocytes. Biochim. Biophys. Acta, 1994, 1224, 517-526.

[145] Lipp, P.; Laine, M.; Tovey, S. C.; Burrell, K. M.; Berridge, M. J.; Li, W.; Bootman, M. D. Functional InsP3 receptors that may modulate excitation-contraction coupling in the heart. Curr. Biol., 2000, 10, 939-942.

[146] Gorza, L.; Schiaffino, S.; Volpe, P. Inositol 1,4,5-trisphosphate receptor in heart: evidence for its concentration in Purkinje myocytes of the conduction system. J. Cell Biol., 1993, 121, 345-353.

[147] Verma, A.; Hirsch, D. J.; Snyder, S. H. Calcium pools mobilized by calcium or inositol 1,4,5-trisphosphate are differentially localized in rat heart and brain. Mol. Biol. Cell, 1992, 3, 621-631.

[148] Wu, X.; Zhang, T.; Bossuyt, J.; Li, X.; McKinsey, T. A.; Dedman, J. R.; Olson, E. N.; Chen, J.; Brown, J. H.; Bers, D. M. Local InsP3-dependent perinuclear $\mathrm{Ca}^{2+}$ signaling in cardiac myocyte excitation-transcription coupling. J. Clin. Invest., 2006, 116, 675-682.

[149] Bootman, M. D.; Collins, T. J.; Mackenzie, L.; Roderick, H. L.; Berridge, M. J.; Peppiatt, C. M. 2-aminoethoxydiphenyl borate (2$\mathrm{APB})$ is a reliable blocker of store-operated $\mathrm{Ca}^{2+}$ entry but an inconsistent inhibitor of InsP3-induced $\mathrm{Ca}^{2+}$ release. FASEB J., 2002 16, 1145-1150.

[150] Harzheim, D.; Talasila, A.; Movassagh, M.; Foo, R. S.; Figg, N.; Bootman, M. D.; Roderick, H. L. Elevated InsP3R expression underlies enhanced calcium fluxes and spontaneous extra-systolic 
calcium release events in hypertrophic cardiac myocytes. Channels, 2010, 4, 67-71.

[151] Liang, X.; Xie, H.; Zhu, P. H.; Hu, J.; Zhao, Q.; Wang, C. S.; Yang, C. Enhanced activity of inositol-1,4,5-trisphosphate receptors in atrial myocytes of atrial fibrillation patients. Cardiology, 2009, 114, 180-191.

[152] Yamda, J.; Ohkusa, T.; Nao, T.; Ueyama, T.; Yano, M.; Kobayashi, S.; Hamano, K.; Esato, K.; Matsuzaki, M. Up-regulation of inositol 1,4,5 trisphosphate receptor expression in atrial tissue in patients with chronic atrial fibrillation. J. Am. Coll. Cardiol., 2001, 37, 1111-1119.

[153] Santulli, G.; Iaccarino, G.; De Luca, N.; Trimarco, B.; Condorelli, G. Atrial fibrillation and microRNAs. Front. Physiol., 2014, 5, 15.

[154] Santulli, G.; D'Ascia S, L.; D'Ascia, C. Development of atrial fibrillation in recipients of cardiac resynchronization therapy: the role of atrial reverse remodelling. Can. J. Cardiol., 2012, 28, 245 e217.

[155] Xiao, J.; Liang, D.; Zhao, H.; Liu, Y.; Zhang, H.; Lu, X.; Liu, Y.; Li, J.; Peng, L.; Chen, Y. H. 2-Aminoethoxydiphenyl borate, a inositol 1,4,5-triphosphate receptor inhibitor, prevents atrial fibrillation. Exp. Biol. Med. (Maywood), 2010, 235, 862-868.

[156] Mouton, R.; Huisamen, B.; Lochner, A. Increased myocardial inositol trisphosphate levels during alpha 1-adrenergic stimulation and reperfusion of ischaemic rat heart. J. Mol. Cell. Cardiol., 1991, $23,841-850$

[157] Du, X. J.; Anderson, K. E.; Jacobsen, A.; Woodcock, E. A.; Dart, A. M. Suppression of ventricular arrhythmias during ischemiareperfusion by agents inhibiting Ins $(1,4,5) \mathrm{P} 3$ release. Circulation, 1995, 91, 2712-2716.

[158] Akhter, S. A.; Luttrell, L. M.; Rockman, H. A.; Iaccarino, G.; Lefkowitz, R. J.; Koch, W. J. Targeting the receptor-Gq interface to inhibit in vivo pressure overload myocardial hypertrophy. Science, 1998, 280, 574-577.

[159] Wakasaki, H.; Koya, D.; Schoen, F. J.; Jirousek, M. R.; Ways, D. K.; Hoit, B. D.; Walsh, R. A.; King, G. L. Targeted overexpression of protein kinase $\mathrm{C}$ beta2 isoform in myocardium causes cardiomyopathy. Proc. Natl. Acad. Sci. U. S. A., 1997, 94, 9320-9325.

[160] Sorriento, D.; Santulli, G.; Fusco, A.; Anastasio, A.; Trimarco, B.; Iaccarino, G. Intracardiac injection of AdGRK5-NT reduces left ventricular hypertrophy by inhibiting NF-kappaB-dependent hypertrophic gene expression. Hypertension, 2010, 56, 696-704.

[161] Rios, E.; Brum, G. Involvement of dihydropyridine receptors in excitation-contraction coupling in skeletal muscle. Nature, 1987, 325, 717-720.

[162] Nelson, B. R.; Wu, F.; Liu, Y.; Anderson, D. M.; McAnally, J.; Lin, W.; Cannon, S. C.; Bassel-Duby, R.; Olson, E. N. Skeletal muscle-specific T-tubule protein STAC3 mediates voltage-induced $\mathrm{Ca}^{2+}$ release and contractility. Proc. Natl. Acad. Sci. U. S. A., 2013, 110, 11881-11886.

[163] Block, B. A.; Imagawa, T.; Campbell, K. P.; Franzini-Armstrong, C. Structural evidence for direct interaction between the molecular components of the transverse tubule/sarcoplasmic reticulum junction in skeletal muscle. J. Cell Biol., 1988, 107, 2587-2600.

[164] Wagenknecht, T.; Grassucci, R.; Frank, J.; Saito, A.; Inui, M.; Fleischer, S. Three-dimensional architecture of the calcium channel/foot structure of sarcoplasmic reticulum. Nature, 1989, 338, 167-170.

[165] Brandt, N. R.; Caswell, A. H.; Wen, S. R.; Talvenheimo, J. A. Molecular interactions of the junctional foot protein and dihydropyridine receptor in skeletal muscle triads. J. Membr. Biol., 1990, $113,237-251$

[166] Takeshima, H.; Iino, M.; Takekura, H.; Nishi, M.; Kuno, J.; Minowa, O.; Takano, H.; Noda, T. Excitation-contraction uncoupling and muscular degeneration in mice lacking functional skeletal muscle ryanodine-receptor gene. Nature, 1994, 369, 556-559.

[167] Takekura, H.; Nishi, M.; Noda, T.; Takeshima, H.; FranziniArmstrong, C. Abnormal junctions between surface membrane and sarcoplasmic reticulum in skeletal muscle with a mutation targeted to the ryanodine receptor. Proc. Natl. Acad. Sci. U. S. A., 1995, 92, 3381-3385.

[168] Nakai, J.; Dirksen, R. T.; Nguyen, H. T.; Pessah, I. N.; Beam, K. G.; Allen, P. D. Enhanced dihydropyridine receptor channel activity in the presence of ryanodine receptor. Nature, 1996, 380, 72-75.

[169] Andersson, D. C.; Meli, A. C.; Reiken, S.; Betzenhauser, M. J.; Umanskaya, A.; Shiomi, T.; D'Armiento, J.; Marks, A. R. Leaky ryanodine receptors in beta-sarcoglycan deficient mice: a potential common defect in muscular dystrophy. Skelet Muscle, 2012, 2, 9.
[170] Bellinger, A. M.; Mongillo, M.; Marks, A. R. Stressed out: the skeletal muscle ryanodine receptor as a target of stress. J. Clin. Invest., 2008, 118, 445-453.

[171] Betzenhauser, M. J.; Marks, A. R. Ryanodine receptor channelopathies. Pflugers Arch., 2010, 460, 467-480.

[172] Censier, K.; Urwyler, A.; Zorzato, F.; Treves, S. Intracellular calcium homeostasis in human primary muscle cells from malignan hyperthermia-susceptible and normal individuals. Effect Of overexpression of recombinant wild-type and Arg163Cys mutated ryanodine receptors. J. Clin. Invest., 1998, 101, 1233-1242.

[173] Larach, M. G.; Brandom, B. W.; Allen, G. C.; Gronert, G. A.; Lehman, E. B. Malignant Hyperthermia Deaths Related to Inadequate Temperature Monitoring, 2007-2012: A Report from The North American Malignant Hyperthermia Registry of the Malignant Hyperthermia Association of the United States. Anesth. Analg., 2014.

[174] Nelson, T. E.; Bee, D. E. Temperature perturbation studies of sarcoplasmic reticulum from malignant hyperthermia pig muscle. $J$. Clin. Invest., 1979, 64, 895-901.

[175] Mickelson, J. R.; Gallant, E. M.; Litterer, L. A.; Johnson, K. M.; Rempel, W. E.; Louis, C. F. Abnormal sarcoplasmic reticulum ryanodine receptor in malignant hyperthermia. J. Biol. Chem., 1988 263, 9310-9315.

[176] Fill, M.; Coronado, R.; Mickelson, J. R.; Vilven, J.; Ma, J. J.; Jacobson, B. A.; Louis, C. F. Abnormal ryanodine receptor channels in malignant hyperthermia. Biophys. J., 1990, 57, 471-475.

[177] Magee, K. R.; Shy, G. M. A new congenital non-progressive myopathy. Brain, 1956, 79, 610-621.

[178] Zhou, H.; Jungbluth, H.; Sewry, C. A.; Feng, L.; Bertini, E.; Bushby, K.; Straub, V.; Roper, H.; Rose, M. R.; Brockington, M.; Kinali, M.; Manzur, A.; Robb, S.; Appleton, R.; Messina, S.; D'Amico, A.; Quinlivan, R.; Swash, M.; Muller, C. R.; Brown, S.; Treves, S.; Muntoni, F. Molecular mechanisms and phenotypic variation in RYR1-related congenital myopathies. Brain, 2007, 130, 2024-2036.

[179] Avila, G.; Dirksen, R. T. Functional effects of central core disease mutations in the cytoplasmic region of the skeletal muscle ryanodine receptor. J. Gen. Physiol., 2001, 118, 277-290.

[180] Bharucha-Goebel, D. X.; Santi, M.; Medne, L.; Zukosky, K.; Dastgir, J.; Shieh, P. B.; Winder, T.; Tennekoon, G.; Finkel, R. S.; Dowling, J. J.; Monnier, N.; Bonnemann, C. G. Severe congenital RYR1-associated myopathy: the expanding clinicopathologic and genetic spectrum. Neurology, 2013, 80, 1584-1589.

[181] Zvaritch, E.; Kraeva, N.; Bombardier, E.; McCloy, R. A.; Depreux, F.; Holmyard, D.; Kraev, A.; Seidman, C. E.; Seidman, J. G.; Tupling, A. R.; MacLennan, D. H. $\mathrm{Ca}^{2+}$ dysregulation in Ryr1(I4895T/wt) mice causes congenital myopathy with progressive formation of minicores, cores, and nemaline rods. Proc. Natl. Acad. Sci. U. S. A., 2009, 106, 21813-21818.

[182] Ferreiro, A.; Monnier, N.; Romero, N. B.; Leroy, J. P.; Bonnemann, C.; Haenggeli, C. A.; Straub, V.; Voss, W. D.; Nivoche, Y.; Jungbluth, H.; Lemainque, A.; Voit, T.; Lunardi, J.; Fardeau, M.; Guicheney, P. A recessive form of central core disease, transiently presenting as multi-minicore disease, is associated with a homozygous mutation in the ryanodine receptor type 1 gene. Ann. Neurol., 2002, 51, 750-759

[183] Bellinger, A. M.; Reiken, S.; Carlson, C.; Mongillo, M.; Liu, X.; Rothman, L.; Matecki, S.; Lacampagne, A.; Marks, A. R. Hypernitrosylated ryanodine receptor calcium release channels are leaky in dystrophic muscle. Nat. Med., 2009, 15, 325-330.

[184] Santulli, G. Adrenal signaling in heart failure: something more than a distant ship's smoke on the horizon. Hypertension, 2014, 63, 215216.

[185] Dalla Libera, L.; Ravara, B.; Gobbo, V.; Danieli Betto, D.; Germinario, E.; Angelini, A.; Vescovo, G. Skeletal muscle myofibrillar protein oxidation in heart failure and the protective effect of Carvedilol. J. Mol. Cell. Cardiol., 2005, 38, 803-807.

[186] Ward, C. W.; Reiken, S.; Marks, A. R.; Marty, I.; Vassort, G.; Lacampagne, A. Defects in ryanodine receptor calcium release in skeletal muscle from post-myocardial infarct rats. FASEB J., 2003 $17,1517-1519$

[187] Bellinger, A. M.; Reiken, S.; Dura, M.; Murphy, P. W.; Deng, S. X.; Landry, D. W.; Nieman, D.; Lehnart, S. E.; Samaru, M.; LaCampagne, A.; Marks, A. R. Remodeling of ryanodine receptor complex causes "leaky" channels: a molecular mechanism for de- 
creased exercise capacity. Proc. Natl. Acad. Sci. U. S. A., 2008, 105, 2198-2202.

[188] Umanskaya, A.; Santulli, G.; Xie, W.; Andersson, D. C.; Reiken, S. R.; Marks, A. R. Genetically enhancing mitochondrial antioxidant activity improves muscle function in aging. Proc. Natl. Acad. Sci. U. S. A., 2014, 111, 15250-15255.

[189] Moschella, M. C.; Watras, J.; Jayaraman, T.; Marks, A. R. Inositol 1,4,5-trisphosphate receptor in skeletal muscle: differential expression in myofibres. J. Muscle Res. Cell Motil., 1995, 16, 390-400.

[190] Salanova, M.; Priori, G.; Barone, V.; Intravaia, E.; Flucher, B.; Ciruela, F.; McIlhinney, R. A.; Parys, J. B.; Mikoshiba, K.; Sorrentino, V. Homer proteins and $\operatorname{Ins} \mathrm{P}(3)$ receptors co-localise in the longitudinal sarcoplasmic reticulum of skeletal muscle fibres. Cell Calcium, 2002, 32, 193-200.

[191] Casas, M.; Figueroa, R.; Jorquera, G.; Escobar, M.; Molgo, J.; Jaimovich, E. IP(3)-dependent, post-tetanic calcium transients induced by electrostimulation of adult skeletal muscle fibers. J. Gen. Physiol., 2010, 136, 455-467.

[192] Stiber, J. A.; Tabatabaei, N.; Hawkins, A. F.; Hawke, T.; Worley, P. F.; Williams, R. S.; Rosenberg, P. Homer modulates NFATdependent signaling during muscle differentiation. Dev. Biol., 2005, 287, 213-224.

[193] Powell, J. A.; Carrasco, M. A.; Adams, D. S.; Drouet, B.; Rios, J.; Muller, M.; Estrada, M.; Jaimovich, E. IP(3) receptor function and localization in myotubes: an unexplored $\mathrm{Ca}(2+)$ signaling pathway in skeletal muscle. J. Cell Sci., 2001, 114, 3673-3683.

[194] Blaauw, B.; Del Piccolo, P.; Rodriguez, L.; Hernandez Gonzalez, V. H.; Agatea, L.; Solagna, F.; Mammano, F.; Pozzan, T.; Schiaffino, S. No evidence for inositol 1,4,5-trisphosphate-dependent $\mathrm{Ca}^{2+}$ release in isolated fibers of adult mouse skeletal muscle. $J$. Gen. Physiol., 2012, 140, 235-241.

[195] Powell, J. A.; Molgo, J.; Adams, D. S.; Colasante, C.; Williams, A.; Bohlen, M.; Jaimovich, E. IP3 receptors and associated $\mathrm{Ca}^{2+}$ signals localize to satellite cells and to components of the neuromuscular junction in skeletal muscle. J. Neurosci., 2003, 23, 81858192.

[196] Lessard, C. B.; Lussier, M. P.; Cayouette, S.; Bourque, G.; Boulay, $\mathrm{G}$. The overexpression of presenilin2 and Alzheimer's-diseaselinked presenilin2 variants influences TRPC6-enhanced $\mathrm{Ca}^{2+}$ entry into HEK293 cells. Cell. Signal., 2005, 17, 437-445.

[197] Zatti, G.; Ghidoni, R.; Barbiero, L.; Binetti, G.; Pozzan, T.; Fasolato, C.; Pizzo, P. The presenilin 2 M239I mutation associated with familial Alzheimer's disease reduces $\mathrm{Ca}^{2+}$ release from intracellular stores. Neurobiol. Dis., 2004, 15, 269-278.

[198] Schapira, A. H.; Olanow, C. W.; Greenamyre, J. T.; Bezard, E. Slowing of neurodegeneration in Parkinson's disease and Huntington's disease: future therapeutic perspectives. Lancet, 2014, 384, 545-555.

[199] Arduino, D. M.; Esteves, A. R.; Cardoso, S. M.; Oliveira, C. R. Endoplasmic reticulum and mitochondria interplay mediates apoptotic cell death: relevance to Parkinson's disease. Neurochem. Int., 2009, 55, 341-348.

[200] Takei, K.; Mignery, G. A.; Mugnaini, E.; Sudhof, T. C.; De Camilli, P. Inositol 1,4,5-trisphosphate receptor causes formation of ER cisternal stacks in transfected fibroblasts and in cerebellar Purkinje cells. Neuron, 1994, 12, 327-342.

[201] Miller, M. C. Commentary. Did Lou Gehrig have Lou Gehrig's disease? Harv. Ment. Health Lett., 2011, 27, 8.

[202] Cleveland, D. W.; Rothstein, J. D. From Charcot to Lou Gehrig: deciphering selective motor neuron death in ALS. Nat. Rev. Neurosci., 2001, 2, 806-819.

[203] Shampo, M. A.; Kyle, R. A. Lou Gehrig--amyotrophic lateral sclerosis. Mayo Clin. Proc., 1993, 68, 929.

[204] Carlesi, C.; Caldarazzolenco, E.; Mancuso, M.; Siciliano, G. Amyotrophic Lateral Sclerosis: A Genetic Point Of View. Curr. Mol. Med., 2014.

[205] Hanrieder, J.; Ewing, A. G. Spatial elucidation of spinal cord lipidand metabolite- regulations in amyotrophic lateral sclerosis. Sci. Rep., 2014, 4, 5266.

[206] Chin, E. R.; Chen, D.; Bobyk, K.; Mazala, D. A. Perturbations in Intracellular $\mathrm{Ca}^{2+}$ Handling in Skeletal Muscle in the G93A*SOD1 Mouse Model of Amyotrophic Lateral Sclerosis. Am. J. Physiol. Cell Physiol., 2014, ajpcell 0023702013.

[207] Tanaka, H.; Shimazawa, M.; Kimura, M.; Takata, M.; Tsuruma, K.; Yamada, M.; Takahashi, H.; Hozumi, I.; Niwa, J.; Iguchi, Y.; Nikawa, T.; Sobue, G.; Inuzuka, T.; Hara, H. The potential of
GPNMB as novel neuroprotective factor in amyotrophic lateral sclerosis. Sci. Rep., 2012, 2, 573.

[208] Turner, M. R.; Goldacre, R.; Ramagopalan, S.; Talbot, K.; Goldacre, M. J. Autoimmune disease preceding amyotrophic lateral sclerosis: an epidemiologic study. Neurology, 2013, 81, 1222-1225.

[209] Antel, J. P.; Richman, D. P.; Arnason, B. G. Immunogenetics and amyotrophic lateral sclerosis. UCLA Forum Med. Sci., 1976, 151171 .

[210] Pagani, M. R.; Reisin, R. C.; Uchitel, O. D. Calcium signaling pathways mediating synaptic potentiation triggered by amyotrophic lateral sclerosis IgG in motor nerve terminals. J. Neurosci., 2006, 26, 2661-2672

[211] van Es, M. A.; Van Vught, P. W.; Blauw, H. M.; Franke, L.; Saris, C. G.; Andersen, P. M.; Van Den Bosch, L.; de Jong, S. W.; van 't Slot, R.; Birve, A.; Lemmens, R.; de Jong, V.; Baas, F.; Schelhaas, H. J.; Sleegers, K.; Van Broeckhoven, C.; Wokke, J. H.; Wijmenga, C.; Robberecht, W.; Veldink, J. H.; Ophoff, R. A.; van den Berg, L. H. ITPR2 as a susceptibility gene in sporadic amyotrophic lateral sclerosis: a genome-wide association study. Lancet Neurol., 2007, 6, 869-877.

[212] Kihira, T.; Utunomiya, H.; Kondo, T. Expression of FKBP12 and ryanodine receptors (RyRs) in the spinal cord of MND patients. Amyotroph. Lateral Scler. Other Motor Neuron Disord., 2005, 6, 94-99.

[213] Rivera, V. M.; Breitbach, W. B.; Swanke, L. Letter: Dantrolene in amyotrophic lateral sclerosis. JAMA, 1975, 233, 863-864.

[214] Chamberlain, B. K.; Volpe, P.; Fleischer, S. Inhibition of calciuminduced calcium release from purified cardiac sarcoplasmic reticulum vesicles. J. Biol. Chem., 1984, 259, 7547-7553.

[215] Zhao, F.; Li, P.; Chen, S. R.; Louis, C. F.; Fruen, B. R. Dantrolene inhibition of ryanodine receptor $\mathrm{Ca}^{2+}$ release channels. Molecular mechanism and isoform selectivity. J. Biol. Chem., 2001, 276, 13810-13816.

[216] Oo, Y. W.; Gomez-Hurtado, N.; Walweel, K.; van Helden, D. F.; Imtiaz, M. S.; Knollmann, B. C.; Laver, D. R. Essential Role of Calmodulin in RyR Inhibition by Dantrolene. Mol. Pharmacol., 2015, 88, 57-63.

[217] Stutzmann, G. E.; Caccamo, A.; LaFerla, F. M.; Parker, I. Dysregulated IP3 signaling in cortical neurons of knock-in mice expressing an Alzheimer's-linked mutation in presenilin1 results in exaggerated $\mathrm{Ca}^{2+}$ signals and altered membrane excitability. J. Neurosci., 2004, 24, 508-513.

[218] Veeranna; Kaji, T.; Boland, B.; Odrljin, T.; Mohan, P.; Basavarajappa, B. S.; Peterhoff, C.; Cataldo, A.; Rudnicki, A.; Amin, N.; Li, B. S.; Pant, H. C.; Hungund, B. L.; Arancio, O.; Nixon, R. A. Calpain mediates calcium-induced activation of the erk1,2 MAPK pathway and cytoskeletal phosphorylation in neurons: relevance to Alzheimer's disease. Am. J. Pathol., 2004, 165, 795-805.

[219] Demuro, A.; Parker, I. Cytotoxicity of intracellular abeta42 amyloid oligomers involves $\mathrm{Ca}^{2+}$ release from the endoplasmic reticulum by stimulated production of inositol trisphosphate. J. Neurosci., 2013, 33, 3824-3833.

[220] Ito, E.; Oka, K.; Etcheberrigaray, R.; Nelson, T. J.; McPhie, D. L.; Tofel-Grehl, B.; Gibson, G. E.; Alkon, D. L. Internal Ca ${ }^{2+}$ mobilization is altered in fibroblasts from patients with Alzheimer disease. Proc. Natl. Acad. Sci. U. S. A., 1994, 91, 534-538.

[221] Cheung, K. H.; Shineman, D.; Muller, M.; Cardenas, C.; Mei, L.; Yang, J.; Tomita, T.; Iwatsubo, T.; Lee, V. M.; Foskett, J. K. Mechanism of $\mathrm{Ca}^{2+}$ disruption in Alzheimer's disease by presenilin regulation of InsP3 receptor channel gating. Neuron, 2008, 58, 871883 .

[222] Shilling, D.; Muller, M.; Takano, H.; Mak, D. O.; Abel, T.; Coulter, D. A.; Foskett, J. K. Suppression of InsP3 receptor-mediated $\mathrm{Ca}^{2+}$ signaling alleviates mutant presenilin-linked familial Alzheimer's disease pathogenesis. J. Neurosci., 2014, 34, 6910-6923.

[223] Kelliher, M.; Fastbom, J.; Cowburn, R. F.; Bonkale, W.; Ohm, T. G.; Ravid, R.; Sorrentino, V.; O'Neill, C. Alterations in the ryanodine receptor calcium release channel correlate with Alzheimer's disease neurofibrillary and beta-amyloid pathologies. Neuroscience, 1999, 92, 499-513.

[224] Stutzmann, G. E.; Smith, I.; Caccamo, A.; Oddo, S.; Parker, I.; Laferla, F. Enhanced ryanodine-mediated calcium release in mutant PS1-expressing Alzheimer's mouse models. Ann. N. Y. Acad. Sci., 2007, 1097, 265-277. 
[225] Liu, J.; Supnet, C.; Sun, S.; Zhang, H.; Good, L.; Popugaeva, E.; Bezprozvanny, I. The role of ryanodine receptor type 3 in a mouse model of Alzheimer disease. Channels, 2014, 8 .

[226] Antonell, A.; Llado, A.; Altirriba, J.; Botta-Orfila, T.; Balasa, M.; Fernandez, M.; Ferrer, I.; Sanchez-Valle, R.; Molinuevo, J. L. A preliminary study of the whole-genome expression profile of sporadic and monogenic early-onset alzheimer's disease. Neurobiol. Aging, 2013, 34, 1772-1778

[227] Alberdi, E.; Wyssenbach, A.; Alberdi, M.; Sanchez-Gomez, M. V.; Cavaliere, F.; Rodriguez, J. J.; Verkhratsky, A.; Matute, C. Ca(2+) -dependent endoplasmic reticulum stress correlates with astrogliosis in oligomeric amyloid beta-treated astrocytes and in a model of Alzheimer's disease. Aging Cell, 2013, 12, 292-302.

[228] Czeredys, M.; Gruszczynska-Biegala, J.; Schacht, T.; Methner, A.; Kuznicki, J. Expression of genes encoding the calcium signalosome in cellular and transgenic models of Huntington's disease. Front. Mol. Neurosci., 2013, 6, 42 .

[229] Sun, Y.; Savanenin, A.; Reddy, P. H.; Liu, Y. F. Polyglutamineexpanded huntingtin promotes sensitization of N-methyl-Daspartate receptors via post-synaptic density 95. J. Biol. Chem., 2001, 276, 24713-24718.

[230] Tang, T. S.; Tu, H.; Chan, E. Y.; Maximov, A.; Wang, Z.; Wellington, C. L.; Hayden, M. R.; Bezprozvanny, I. Huntingtin and huntingtin-associated protein 1 influence neuronal calcium signaling mediated by inositol-(1,4,5) triphosphate receptor type 1 . Neuron, 2003, 39, 227-239.

[231] Kaltenbach, L. S.; Romero, E.; Becklin, R. R.; Chettier, R.; Bell, R.; Phansalkar, A.; Strand, A.; Torcassi, C.; Savage, J.; Hurlburt, A.; Cha, G. H.; Ukani, L.; Chepanoske, C. L.; Zhen, Y.; Sahasrabudhe, S.; Olson, J.; Kurschner, C.; Ellerby, L. M.; Peltier, J. M.; Botas, J.; Hughes, R. E. Huntingtin interacting proteins are genetic modifiers of neurodegeneration. PLoS Genet., 2007, 3, e82.

[232] Hoge, C. W.; Castro, C. A. Treatment of generalized war-related health concerns: placing TBI and PTSD in context. JAMA, 2014, 312, 1685-1686

[233] Harvey, B. H.; Naciti, C.; Brand, L.; Stein, D. J. Serotonin and stress: protective or malevolent actions in the biobehavioral response to repeated trauma? Ann. N. Y. Acad. Sci., 2004, 1032, 267272.

[234] Liu, H.; Han, F.; Shi, Y. Effect of calreticulin on $\mathrm{Ca}^{2+} / \mathrm{CaM}$ kinaseIIalpha and endoplasmic reticulum stress in hippocampal in a rat model of post-traumatic stress disorder. Neurochem. Res., 2013, 38, 1407-1414.

[235] Jacobi, H.; Bauer, P.; Giunti, P.; Labrum, R.; Sweeney, M. G.; Charles, P.; Durr, A.; Marelli, C.; Globas, C.; Linnemann, C.; Schols, L.; Rakowicz, M.; Rola, R.; Zdzienicka, E.; SchmitzHubsch, T.; Fancellu, R.; Mariotti, C.; Tomasello, C.; Baliko, L.; Melegh, B.; Filla, A.; Rinaldi, C.; van de Warrenburg, B. P.; Verstappen, C. C.; Szymanski, S.; Berciano, J.; Infante, J.; Timmann, D.; Boesch, S.; Hering, S.; Depondt, C.; Pandolfo, M.; Kang, J. S.; Ratzka, S.; Schulz, J.; Tezenas du Montcel, S.; Klockgether, T. The natural history of spinocerebellar ataxia type 1,2, 3, and 6: a 2-year follow-up study. Neurology, 2011, 77, 1035-1041.

[236] Matsumoto, M.; Nakagawa, T.; Inoue, T.; Nagata, E.; Tanaka, K.; Takano, H.; Minowa, O.; Kuno, J.; Sakakibara, S.; Yamada, M.; Yoneshima, H.; Miyawaki, A.; Fukuuchi, Y.; Furuichi, T.; Okano, H.; Mikoshiba, K.; Noda, T. Ataxia and epileptic seizures in mice lacking type 1 inositol 1,4,5-trisphosphate receptor. Nature, 1996, 379, 168-171.

[237] Liu, J.; Tang, T. S.; Tu, H.; Nelson, O.; Herndon, E.; Huynh, D. P.; Pulst, S. M.; Bezprozvanny, I. Deranged calcium signaling and neurodegeneration in spinocerebellar ataxia type 2. J. Neurosci., 2009, 29, 9148-9162.

[238] Chen, X.; Tang, T. S.; Tu, H.; Nelson, O.; Pook, M.; Hammer, R.; Nukina, N.; Bezprozvanny, I. Deranged calcium signaling and neurodegeneration in spinocerebellar ataxia type 3. J. Neurosci., 2008, $28,12713-12724$.

[239] van de Leemput, J.; Chandran, J.; Knight, M. A.; Holtzclaw, L. A.; Scholz, S.; Cookson, M. R.; Houlden, H.; Gwinn-Hardy, K.; Fung, H. C.; Lin, X.; Hernandez, D.; Simon-Sanchez, J.; Wood, N. W.; Giunti, P.; Rafferty, I.; Hardy, J.; Storey, E.; Gardner, R. J.; Forrest, S. M.; Fisher, E. M.; Russell, J. T.; Cai, H.; Singleton, A. B. Deletion at ITPR1 underlies ataxia in mice and spinocerebellar ataxia 15 in humans. PLoS Genet., 2007, 3, e108.

[240] Iwaki, A.; Kawano, Y.; Miura, S.; Shibata, H.; Matsuse, D.; Li, W.; Furuya, H.; Ohyagi, Y.; Taniwaki, T.; Kira, J.; Fukumaki, Y. Het- erozygous deletion of ITPR1, but not SUMF1, in spinocerebellar ataxia type 16. J. Med. Genet., 2008, 45, 32-35.

[241] Street, V. A.; Bosma, M. M.; Demas, V. P.; Regan, M. R.; Lin, D. D.; Robinson, L. C.; Agnew, W. S.; Tempel, B. L. The type 1 inositol 1,4,5-trisphosphate receptor gene is altered in the opisthotonos mouse. J. Neurosci., 1997, 17, 635-645.

[242] Ye, R.; Ni, M.; Wang, M.; Luo, S.; Zhu, G.; Chow, R. H.; Lee, A $\mathrm{S}$. Inositol 1,4,5-trisphosphate receptor 1 mutation perturbs glucose homeostasis and enhances susceptibility to diet-induced diabetes. $J$. Endocrinol., 2011, 210, 209-217.

[243] Tubbs, E.; Theurey, P.; Vial, G.; Bendridi, N.; Bravard, A.; Chauvin, M. A.; Ji-Cao, J.; Zoulim, F.; Bartosch, B.; Ovize, M.; Vidal, H.; Rieusset, J. Mitochondria-associated endoplasmic reticulum membrane (MAM) integrity is required for insulin signaling and is implicated in hepatic insulin resistance. Diabetes, 2014, 63, 3279. 3294

[244] Tsai, S. H.; Chang, E. Y.; Chang, Y. C.; Hee, S. W.; Tsai, Y. C.; Chang, T. J.; Chuang, L. M. Knockdown of RyR3 enhances adiponectin expression through an atf3-dependent pathway. Endocrinology, 2013, 154, 1117-1129.

[245] Santulli, G. Effects of low-carbohydrate and low-fat diets. Ann. Intern. Med., 2015, 162, 392.

[246] Waluk, D. P.; Vielfort, K.; Derakhshan, S.; Aro, H.; Hunt, M. C. NAcyl taurines trigger insulin secretion by increasing calcium flux in pancreatic beta-cells. Biochem. Biophys. Res. Commun., 2013, 430, 54-59.

[247] De Marchi, U.; Thevenet, J.; Hermant, A.; Dioum, E.; Wiederkehr, A. Calcium co-regulates oxidative metabolism and ATP synthasedependent respiration in pancreatic beta cells. J. Biol. Chem., 2014 289, 9182-9194.

[248] DeFronzo, R. A. Banting Lecture. From the triumvirate to the ominous octet: a new paradigm for the treatment of type 2 diabetes mellitus. Diabetes, 2009, 58, 773-795

[249] Santulli, G.; Lombardi, A.; Sorriento, D.; Anastasio, A.; Del Giudice, C.; Formisano, P.; Beguinot, F.; Trimarco, B.; Miele, C.; Iaccarino, G. Age-related impairment in insulin release: the essential role of beta(2)-adrenergic receptor. Diabetes, 2012, 61, 692 701.

[250] Lee, B.; Laychock, S. G. Inositol 1,4,5-trisphosphate receptor isoform expression in mouse pancreatic islets: effects of carbachol. Biochem. Pharmacol., 2001, 61, 327-336.

[251] Madec, A. M.; Cassel, R.; Dubois, S.; Ducreux, S.; Vial, G.; Chauvin, M. A.; Mesnier, A.; Chikh, K.; Bosco, D.; Rieusset, J.; Van Coppenolle, F.; Thivolet, C. Losartan, an angiotensin II type 1 receptor blocker, protects human islets from glucotoxicity through the phospholipase C pathway. FASEB J., 2013, 27, 5122-5130.

[252] Johnson, J. D.; Kuang, S.; Misler, S.; Polonsky, K. S. Ryanodine receptors in human pancreatic beta cells: localization and effects on insulin secretion. FASEB J., 2004, 18, 878-880.

[253] Dror, V.; Kalynyak, T. B.; Bychkivska, Y.; Frey, M. H.; Tee, M.; Jeffrey, K. D.; Nguyen, V.; Luciani, D. S.; Johnson, J. D. Glucose and endoplasmic reticulum calcium channels regulate HIF-1beta via presenilin in pancreatic beta-cells. J. Biol. Chem., 2008, 283, 9909-9916.

[254] Dadi, P. K.; Vierra, N. C.; Ustione, A.; Piston, D. W.; Colbran, R J.; Jacobson, D. A. Inhibition of pancreatic beta-cell $\mathrm{Ca}^{2+}$ /calmodulin-dependent protein kinase II reduces glucose-stimulated calcium influx and insulin secretion, impairing glucose tolerance. $J$. Biol. Chem., 2014, 289, 12435-12445.

[255] Futatsugi, A.; Nakamura, T.; Yamada, M. K.; Ebisui, E.; Nakamura, K.; Uchida, K.; Kitaguchi, T.; Takahashi-Iwanaga, H.; Noda, T.; Aruga, J.; Mikoshiba, K. IP3 receptor types 2 and 3 mediate exocrine secretion underlying energy metabolism. Science, $\mathbf{2 0 0 5}$ 309, 2232-2234

[256] Roach, J. C.; Deutsch, K.; Li, S.; Siegel, A. F.; Bekris, L. M.; Einhaus, D. C.; Sheridan, C. M.; Glusman, G.; Hood, L.; Lernmark A.; Janer, M. Genetic mapping at 3-kilobase resolution reveals inositol 1,4,5-triphosphate receptor 3 as a risk factor for type 1 diabetes in Sweden. Am. J. Hum. Genet., 2006, 79, 614-627.

[257] Qu, H. Q.; Marchand, L.; Szymborski, A.; Grabs, R.; Polychronakos, C. The association between type 1 diabetes and the ITPR3 gene polymorphism due to linkage disequilibrium with HLA class II. Genes Immun., 2008, 9, 264-266.

[258] Srivastava, M.; Atwater, I.; Glasman, M.; Leighton, X.; Goping, G.; Caohuy, H.; Miller, G.; Pichel, J.; Westphal, H.; Mears, D.; Rojas, E.; Pollard, H. B. Defects in inositol 1,4,5-trisphosphate recep- 
tor expression, $\mathrm{Ca}(2+)$ signaling, and insulin secretion in the anx7(+/-) knockout mouse. Proc. Natl. Acad. Sci. U. S. A., 1999, 96, 13783-13788

[259] Dyachok, O.; Tufveson, G.; Gylfe, E. $\mathrm{Ca}^{2+}$-induced $\mathrm{Ca}^{2+}$ release by activation of inositol 1,4,5-trisphosphate receptors in primary pancreatic beta-cells. Cell Calcium, 2004, 36, 1-9.

[260] Lemmens, R.; Larsson, O.; Berggren, P. O.; Islam, M. S. $\mathrm{Ca}^{2+}$ induced $\mathrm{Ca}^{2+}$ release from the endoplasmic reticulum amplifies the $\mathrm{Ca}^{2+}$ signal mediated by activation of voltage-gated L-type $\mathrm{Ca}^{2+}$ channels in pancreatic beta-cells. J. Biol. Chem., 2001, 276, 99719977.

[261] Mitchell, K. J.; Lai, F. A.; Rutter, G. A. Ryanodine receptor type I and nicotinic acid adenine dinucleotide phosphate receptors mediate $\mathrm{Ca}^{2+}$ release from insulin-containing vesicles in living pancreatic beta-cells (MIN6). J. Biol. Chem., 2003, 278, 11057-11064.

[262] Noguchi, N.; Yoshikawa, T.; Ikeda, T.; Takahashi, I.; Shervani, N. J.; Uruno, A.; Yamauchi, A.; Nata, K.; Takasawa, S.; Okamoto, H.; Sugawara, A. FKBP12.6 disruption impairs glucose-induced insulin secretion. Biochem. Biophys. Res. Commun., 2008, 371, 735740.

[263] Sardu, C.; Marfella, R.; Santulli, G. Impact of diabetes mellitus on the clinical response to cardiac resynchronization therapy in elderly people. J. Cardiovasc. Transl. Res., 2014, 7, 362-368.

[264] Marks, A. R. Calcium cycling proteins and heart failure: mechanisms and therapeutics. J. Clin. Invest., 2013, 123, 46-52.

[265] Applegate, T. L.; Karjalainen, A.; Bygrave, F. L. Rapid $\mathrm{Ca}^{2+}$ influx induced by the action of dibutylhydroquinone and glucagon in the perfused rat liver. Biochem. J., 1997, 323 (Pt 2), 463-467.

[266] Ozcan, L.; Wong, C. C.; Li, G.; Xu, T.; Pajvani, U.; Park, S. K.; Wronska, A.; Chen, B. X.; Marks, A. R.; Fukamizu, A.; Backs, J.; Singer, H. A.; Yates, J. R., 3rd; Accili, D.; Tabas, I. Calcium signaling through CaMKII regulates hepatic glucose production in fasting and obesity. Cell Metab., 2012, 15, 739-751.

[267] Wang, Y.; Li, G.; Goode, J.; Paz, J. C.; Ouyang, K.; Screaton, R.; Fischer, W. H.; Chen, J.; Tabas, I.; Montminy, M. Inositol-1,4,5trisphosphate receptor regulates hepatic gluconeogenesis in fasting and diabetes. Nature, 2012, 485, 128-132.

[268] Contreras-Ferrat, A.; Llanos, P.; Vasquez, C.; Espinosa, A.; Osorio-Fuentealba, C.; Arias-Calderon, M.; Lavandero, S.; Klip, A.; Hidalgo, C.; Jaimovich, E. Insulin elicits a ROS-activated and an IP3-dependent $\mathrm{Ca}^{2+}$ release, which both impinge on GLUT4 translocation. J. Cell Sci., 2014, 127, 1911-1923.
[269] Weinstein, S. P.; O'Boyle, E.; Haber, R. S. Thyroid hormone increases basal and insulin-stimulated glucose transport in skeletal muscle. The role of GLUT4 glucose transporter expression. Diabe tes, 1994, 43, 1185-1189.

[270] Rogers, M. A.; Evans, W. J. Changes in skeletal muscle with aging: effects of exercise training. Exerc. Sport Sci. Rev., 1993, 21, 65102.

[271] Gonzalez, E.; Messi, M. L.; Zheng, Z.; Delbono, O. Insulin-like growth factor-1 prevents age-related decrease in specific force and intracellular $\mathrm{Ca}^{2+}$ in single intact muscle fibres from transgenic mice. J. Physiol., 2003, 552, 833-844.

[272] Herndon, L. A.; Schmeissner, P. J.; Dudaronek, J. M.; Brown, P. A.; Listner, K. M.; Sakano, Y.; Paupard, M. C.; Hall, D. H.; Driscoll, M. Stochastic and genetic factors influence tissue-specific decline in ageing C. elegans. Nature, 2002, 419, 808-814.

[273] Iwasa, H.; Yu, S.; Xue, J.; Driscoll, M. Novel EGF pathway regulators modulate C. elegans healthspan and lifespan via EGF receptor, PLC-gamma, and IP3R activation. Aging Cell, 2010, 9, 490-505.

[274] Thomas, M. M.; Vigna, C.; Betik, A. C.; Tupling, A. R.; Hepple, R. $\mathrm{T}$. Initiating treadmill training in late middle age offers modest adaptations in $\mathrm{Ca}^{2+}$ handling but enhances oxidative damage in senescent rat skeletal muscle. Am. J. Physiol. Regul. Integr. Comp. Physiol., 2010, 298, R1269-1278.

[275] Klitgaard, H.; Ausoni, S.; Damiani, E. Sarcoplasmic reticulum of human skeletal muscle: age-related changes and effect of training. Acta Physiol., 1989, 137, 23-31.

[276] Russ, D. W.; Grandy, J. S.; Toma, K.; Ward, C. W. Ageing, but not yet senescent, rats exhibit reduced muscle quality and sarcoplasmic reticulum function. Acta Physiol., 2011, 201, 391-403.

[277] Xiao, R. P.; Spurgeon, H. A.; O'Connor, F.; Lakatta, E. G. Ageassociated changes in beta-adrenergic modulation on rat cardiac excitation-contraction coupling. J. Clin. Invest., 1994, 94, 20512059

[278] Lim, C. C.; Apstein, C. S.; Colucci, W. S.; Liao, R. Impaired cell shortening and relengthening with increased pacing frequency are intrinsic to the senescent mouse cardiomyocyte. J. Mol. Cell. Cardiol., 2000, 32, 2075-2082.

[279] Isenberg, G.; Borschke, B.; Rueckschloss, U. $\mathrm{Ca}^{2+}$ transients of cardiomyocytes from senescent mice peak late and decay slowly. Cell Calcium, 2003, 34, 271-280.

[280] Santulli, G.; Totary-Jain, H. Tailoring mTOR-based therapy: molecular evidence and clinical challenges. Pharmacogenomics, 2013, $14,1517-1526$ 